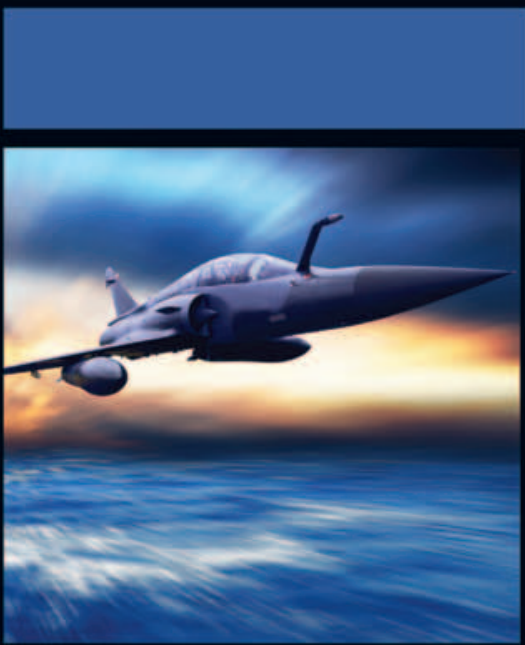

Advanced

Composite Materials

for Aerospace

Engineering

Processing, Properties

and Applications

Edited by Sohel Rana and Raul Fangueiro 
Advanced Composite Materials

for Aerospace Engineering 


\section{Related titles}

Modelling of Failure in Advanced Composite Materials (ISBN 978-0-08100-332-9)

Recent Advances in Smart Self-healing Polymers and Composites (ISBN 978-1-78242-280-8)

Predicting Structural Integrity and Durability in Advanced Composite Materials (ISBN 978-0-08100-137-0) 


\section{Woodhead Publishing Series in Composites}

Science and Engineering: Number 70

\section{Advanced Composite Materials for Aerospace Engineering}

Processing, Properties and Applications

Edited by

Sohel Rana

Raul Fangueiro

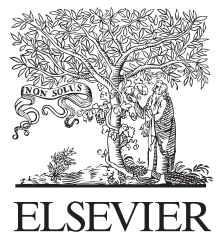

AMSTERDAM • BOSTON • CAMBRIDGE • HEIDELBERG

LONDON • NEW YORK • OXFORD • PARIS • SAN DIEGO SAN FRANCISCO • SINGAPORE • SYDNEY • TOKYO

Woodhead Publishing is an imprint of Elsevier

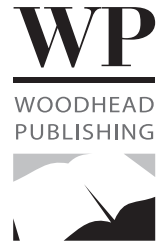


Woodhead Publishing is an imprint of Elsevier

The Officers' Mess Business Centre, Royston Road, Duxford, CB22 4QH, UK

50 Hampshire Street, 5th Floor, Cambridge, MA 02139, USA

The Boulevard, Langford Lane, Kidlington, OX5 1GB, UK

Copyright (c) 2016 Elsevier Ltd. All rights reserved.

No part of this publication may be reproduced or transmitted in any form or by any means, electronic or mechanical, including photocopying, recording, or any information storage and retrieval system, without permission in writing from the publisher. Details on how to seek permission, further information about the Publisher's permissions policies and our arrangements with organizations such as the Copyright Clearance Center and the Copyright Licensing Agency, can be found at our website: www. elsevier.com/permissions.

This book and the individual contributions contained in it are protected under copyright by the Publisher (other than as may be noted herein).

\section{Notices}

Knowledge and best practice in this field are constantly changing. As new research and experience broaden our understanding, changes in research methods, professional practices, or medical treatment may become necessary.

Practitioners and researchers must always rely on their own experience and knowledge in evaluating and using any information, methods, compounds, or experiments described herein. In using such information or methods they should be mindful of their own safety and the safety of others, including parties for whom they have a professional responsibility.

To the fullest extent of the law, neither the Publisher nor the authors, contributors, or editors, assume any liability for any injury and/or damage to persons or property as a matter of products liability, negligence or otherwise, or from any use or operation of any methods, products, instructions, or ideas contained in the material herein.

\section{British Library Cataloguing-in-Publication Data}

A catalogue record for this book is available from the British Library

\section{Library of Congress Cataloging-in-Publication Data}

A catalog record for this book is available from the Library of Congress

ISBN: 978-0-08-100939-0 (print)

ISBN: 978-0-08-100054-0 (online)

For information on all Woodhead Publishing publications visit our website at https://www.elsevier.com/

\section{3eren to grow libraries in $\underset{\text { ELSEVIER }}{\substack{\text { Book Aid } \\ \text { International developing countries }}}$ \\ www.elsevier.com • www.bookaid.org}

Publisher: Matthew Deans

Acquisition Editor: Gwen Jones

Editorial Project Manager: Charlotte Cockle

Production Project Manager: Omer Mukthar

Designer: Victoria Pearson Esser

Typeset by TNQ Books and Journals 
Dedicated to my mentor and dearest grandfather, Md. Abdur Razzaque and my lovely wife, Gargi whose love and inspiration are always behind every piece of my work, including this book.

\section{- Sohel Rana}

Dedicated to my wife Ana and my daughters Carolina, Ana João and Inês... with you everything is possible!

- Raul Fangueiro 
This page intentionally left blank 


\section{Contents}

List of contributors xiii

Woodhead Publishing Series in Composites Science and Engineering xv

Editors' biographies $\quad$ xix

Preface $\quad$ xxi

1 Advanced composites in aerospace engineering 1

S. Rana, R. Fangueiro

1.1 Introduction and current scenario 1

1.2 Types of advanced composite materials $\quad \mathbf{4}$

1.3 Conclusion $\mathbf{1 4}$

References $\quad 14$

2 Advanced fibrous architectures for composites in aerospace engineering

Y. Liu, M. de Araujo, H. Hu

$\begin{array}{ll}2.1 \text { Introduction } & 17\end{array}$

2.2 Types of fibrous architectures $\quad 19$

2.3 2D fibrous architectures $\quad \mathbf{2 0}$

2.4 3D fibrous architectures $\quad \mathbf{2 5}$

2.5 Hybrid fibrous architectures $\quad \mathbf{3 3}$

2.6 Production techniques $\mathbf{3 4}$

2.7 Properties of advanced fibrous architectures: advantages and disadvantages $\quad 49$

2.8 Applications $\quad \mathbf{5 2}$

2.9 Summary and concluding remarks $\quad \mathbf{5 6}$

Sources of further information $\quad \mathbf{5 7}$

References $\quad \mathbf{5 7}$

3 Metal and ceramic matrix composites in aerospace engineering $\quad 59$

F.J. Lino Alves, A.M. Baptista, A.T. Marques

3.1 Introduction $\quad \mathbf{5 9}$

3.2 Types of matrix $\quad \mathbf{6 2}$

3.3 Types of fibre $\quad \mathbf{6 4}$

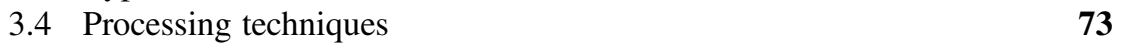

3.5 Joining and repair techniques $\quad \mathbf{8 0}$ 
$\begin{array}{llr}3.6 & \text { Properties } & \mathbf{8 3}\end{array}$

3.7 Modelling $\quad \mathbf{8 6}$

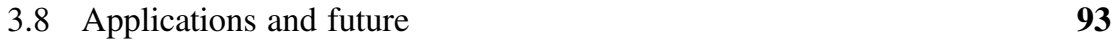

$\begin{array}{ll}3.9 \text { Conclusions } & 97\end{array}$

References $\quad 98$

4 Fibre-reinforced laminates in aerospace engineering 101

L.Z. Linganiso, R.D. Anandjiwala

4.1 Introduction $\quad \mathbf{1 0 1}$

4.2 Technical requirements in the aerospace sector $\quad \mathbf{1 0 5}$

$\begin{array}{ll}\text { 4.3 Advanced laminated composites for aerospace engineering } & \mathbf{1 0 7}\end{array}$

$\begin{array}{lll}\text { 4.4 Matrix systems } & \mathbf{1 1 7}\end{array}$

4.5 Fibre direction and stacking sequence design for FMLs 121

$\begin{array}{lll}4.6 & \text { Future perspective and applications } & \mathbf{1 2 2}\end{array}$

$\begin{array}{ll}4.7 \text { Conclusions } & 123\end{array}$

References $\quad 123$

5 Sandwiched composites in aerospace engineering 129

J.P. Nunes, J.F. Silva

5.1 Introduction $\quad 129$

5.2 Sandwiched composite structures $\quad \mathbf{1 3 0}$

$\begin{array}{ll}\text { 5.3 Design of sandwich structures } & \mathbf{1 5 7}\end{array}$

5.4 Quality control, maintenance, testing, inspection and repairing $\mathbf{1 7 0}$

$\begin{array}{lr}5.5 \text { Conclusions } & \mathbf{1 7 3}\end{array}$

References $\quad 173$

6 Braided composites in aerospace engineering $\mathbf{1 7 5}$

J.P. Carey, G.W. Melenka, A. Hunt, B. Cheung, M. Ivey, C. Ayranci

6.1 Introduction $\quad \mathbf{1 7 5}$

$\begin{array}{ll}\text { 6.2 Definition and concept } & \mathbf{1 7 6}\end{array}$

6.3 Advantages 180

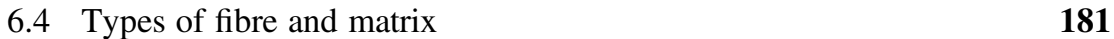

$\begin{array}{lll}6.5 & \text { Production methods } & \mathbf{1 8 4}\end{array}$

6.6 Properties 188

$\begin{array}{lll}6.7 \text { Modelling } & \mathbf{1 9 0}\end{array}$

6.8 Joining techniques $\quad \mathbf{2 0 3}$

$\begin{array}{lll}6.9 & \text { Applications } & \mathbf{2 0 4}\end{array}$

Sources of further information and advice $\quad \mathbf{2 0 6}$

$\begin{array}{ll}\text { References } & \mathbf{2 0 7}\end{array}$

7 Auxetic composites in aerospace engineering 213

Z. Wang, A. Zulifqar, $\mathrm{H}$. $\mathrm{Hu}$

$\begin{array}{lll}7.1 & \text { Introduction } & \mathbf{2 1 3}\end{array}$

$\begin{array}{ll}7.2 & \text { Definition and concept } \\ & \mathbf{2 1 4}\end{array}$

$\begin{array}{lll}7.3 & \text { Advantages and disadvantages } & \mathbf{2 1 4}\end{array}$ 
7.4 Types of auxetic composites

7.5 Properties

7.6 Modelling

7.7 Applications

7.8 Conclusions 238

References

8 Polymer nanocomposite: an advanced material for aerospace applications

M. Joshi, U. Chatterjee

8.1 Introduction $\mathbf{2 4 1}$

8.2 Polymeric parts in aerospace engineering: present state of the art $\mathbf{2 4 2}$

8.3 Polymer nanocomposite: the leading-edge material $\mathbf{2 4 4}$

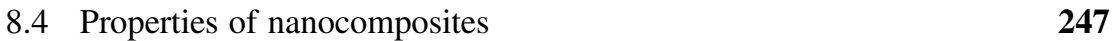

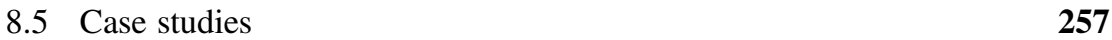

8.6 Some commercial applications $\quad \mathbf{2 6 0}$

8.7 Conclusion $\quad \mathbf{2 6 0}$

References $\quad 261$

9 Multiscale composites for aerospace engineering 265

S. Rana, S. Parveen, R. Fangueiro

9.1 Introduction $\quad \mathbf{2 6 5}$

9.2 Definition and concept $\mathbf{2 6 6}$

9.3 Types of nanomaterials $\quad \mathbf{2 6 7}$

9.4 Fabrication of multiscale composites $\quad \mathbf{2 6 8}$

9.5 Fabrication of multiscale composites

9.6 Mechanical performance of multiscale composites

9.7 Electromagnetic shielding $\quad \mathbf{2 8 4}$

9.8 Strain and damage sensing with multiscale composites $\quad \mathbf{2 8 6}$

9.9 Dimensional stability of multiscale composites $\quad \mathbf{2 8 7}$

9.10 Applications of multiscale composites in aerospace engineering $\quad \mathbf{2 8 8}$

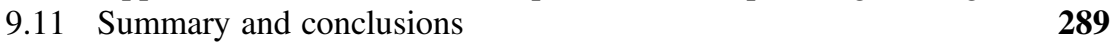

References $\quad 290$

10 Self-sensing structural composites in aerospace engineering 295 D.D.L. Chung

10.1 Introduction to self-sensing $\mathbf{2 9 5}$

10.2 Electrical-resistance-based self-sensing $\mathbf{2 9 6}$

10.3 Electrical configurations for self-sensing $\quad \mathbf{2 9 7}$

10.4 Spatial distribution sensing 301

10.5 Structural composites in aerospace engineering $\quad \mathbf{3 0 3}$

10.6 Sensing strain or stress $\quad \mathbf{3 0 5}$

10.7 Sensing damage $\quad 313$

10.8 Sensing temperature $\quad 320$

10.9 Sensing both strain/stress and mechanical damage $\mathbf{3 2 3}$ 
10.10 Sensing both temperature and thermal damage $\mathbf{3 2 3}$

$\begin{array}{ll}10.11 \text { Modelling of self-sensing } & 324\end{array}$

10.12 Applications of self-sensing composites in aerospace engineering $\mathbf{3 2 5}$

$\begin{array}{ll}10.13 \text { Conclusion } & 325\end{array}$

References $\quad 326$

11 Self-healing composites for aerospace applications 333

R. Das, C. Melchior, K.M. Karumbaiah

11.1 Introduction $\quad 333$

$\begin{array}{lll}11.2 & \text { Self-healing concept } & \mathbf{3 3 4}\end{array}$

$\begin{array}{lll}11.3 & \text { Self-healing approaches } & \mathbf{3 3 7}\end{array}$

11.4 Self-healing composite constituent materials $\quad \mathbf{3 4 2}$

11.5 Functionality recovery in self-healing composites 349

11.6 Applications of self-healing composites $\quad 354$

$\begin{array}{lll}11.7 & \text { Summary } & 359\end{array}$

References $\quad 359$

12 Natural fibre and polymer matrix composites and their applications in aerospace engineering

P. Balakrishnan, M.J. John, L. Pothen, M.S. Sreekala, S. Thomas

12.1 Introduction

12.2 Advantages of NFCs $\quad \mathbf{3 6 8}$

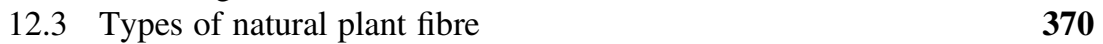

$\begin{array}{lll}12.4 & \text { Types of matrices } & 372\end{array}$

$\begin{array}{ll}12.5 & \text { Green composites } \\ 12.6 & \mathbf{3 7 5}\end{array}$

$\begin{array}{ll}12.6 & \text { Limitations of natural fibres } \\ 12.7 & \mathbf{3 7 6}\end{array}$

12.7 Techniques for improving performance 377

12.8 Prediction of properties: influence of factors 379

12.9 Applications of polymers and polymer composites $\mathbf{3 8 0}$

$\begin{array}{ll}12.10 \text { Conclusion } & 381\end{array}$

References $\quad 381$

13 Carbon-carbon composites in aerospace engineering 385

C. Scarponi

13.1 Introduction $\quad 385$

13.2 Concept of $\mathrm{C}-\mathrm{C}$ composites $\quad \mathbf{3 8 7}$

13.3 Processing of $\mathrm{C}-\mathrm{C}$ materials $\quad 388$

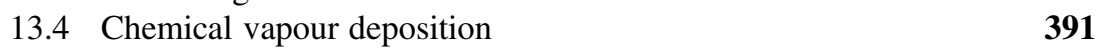

13.5 C-C composites from CNTs 395

13.6 Structure of $\mathrm{C}-\mathrm{C}$ composites 396

$13.7 \mathrm{C}-\mathrm{C}$ properties 399

$\begin{array}{lll}13.8 & \text { Frictional properties } & \mathbf{4 0 5}\end{array}$

13.9 Electrical properties $\quad \mathbf{4 0 5}$

13.10 Biocompatibility $\quad \mathbf{4 0 6}$

$\begin{array}{ll}13.11 & \text { Oxidation } \\ & 406\end{array}$ 
13.12 Applications $\quad \mathbf{4 0 8}$

$13.13 \mathrm{C}-\mathrm{C}$ joining $\quad 409$

13.14 Conclusions $\quad 411$

Acknowledgements $\quad \mathbf{4 1 1}$

References $\quad 411$

14 Product design for advanced composite materials in aerospace engineering

K.V.N. Gopal

14.1 Introduction

14.2 Design strategy $\quad \mathbf{4 1 4}$

14.3 Factors that influence product design $\mathbf{4 1 6}$

$\begin{array}{ll}14.4 & \text { Design methods }\end{array}$

$\begin{array}{lll}14.5 & \text { Design tools } & \mathbf{4 2 1}\end{array}$

14.6 Case studies in product design $\quad \mathbf{4 2 4}$

14.7 Example 1: an Airbus H160 all-composite helicopter 426

14.8 Example 2: Scaled Composites' White Knight Two 426

14.9 Example 3: CMCs for next-generation engines $\quad \mathbf{4 2 7}$

$\begin{array}{ll}14.10 & \text { Conclusions } \\ & \mathbf{4 2 7}\end{array}$

References $\quad \mathbf{4 2 8}$

15 Quality control and testing methods for advanced composite materials in aerospace engineering

Z. Fawaz

15.1 Introduction $\quad \mathbf{4 2 9}$

15.2 Quality control $\mathbf{4 3 0}$

15.3 Destructive testing $\quad \mathbf{4 3 6}$

15.4 Nondestructive testing $\quad \mathbf{4 4 3}$

$\begin{array}{lll}15.5 & \text { Airworthiness considerations } & 447\end{array}$

15.6 Conclusion $\quad \mathbf{4 5 0}$

References $\quad 450$

16 Conclusions and future trends $\quad 453$

$S$. Rana, R. Fangueiro

16.1 Summary $\quad \mathbf{4 5 3}$

16.2 Conclusion and future trends $\quad \mathbf{4 5 5}$

Further reading $\quad 456$

$\begin{array}{ll}\text { Index } & 457\end{array}$ 
This page intentionally left blank 


\section{List of contributors}

R.D. Anandjiwala CSIR Materials Science and Manufacturing, Port Elizabeth, South Africa; Faculty of Science, Nelson Mandela Metropolitan University, Port Elizabeth, South Africa

C. Ayranci University of Alberta, Edmonton, AB, Canada

P. Balakrishnan Mahatma Gandhi University, Kottayam, Kerala, India

A.M. Baptista University of Porto, Porto, Portugal

J.P. Carey University of Alberta, Edmonton, AB, Canada

U. Chatterjee Indian Institute of Technology, New Delhi, India

B. Cheung University of Alberta, Edmonton, AB, Canada

D.D.L. Chung State University of New York, Buffalo, NY, United States

R. Das University of Auckland, Auckland, New Zealand

M. de Araujo University of Minho, Guimarães, Portugal

R. Fangueiro School of Engineering, University of Minho, Guimarães, Portugal

Z. Fawaz Ryerson University, Toronto, ON, Canada

K.V.N. Gopal Indian Institute of Technology Madras, Chennai, India

H. Hu Hong Kong Polytechnic University, Kowloon, Hong Kong

A. Hunt University of Alberta, Edmonton, AB, Canada

M. Ivey University of Alberta, Edmonton, AB, Canada

M.J. John CSIR Materials Science and Manufacturing, Port Elizabeth, South Africa

M. Joshi Indian Institute of Technology, New Delhi, India

K.M. Karumbaiah University of Auckland, Auckland, New Zealand

L.Z. Linganiso CSIR Materials Science and Manufacturing, Port Elizabeth, South Africa

F.J. Lino Alves University of Porto, Porto, Portugal 
Y. Liu Hong Kong Polytechnic University, Kowloon, Hong Kong
A.T. Marques University of Porto, Porto, Portugal
C. Melchior National Polytechnic Institute of Chemical Engineering and Technology (INP-ENSIACET), Toulouse, France

G.W. Melenka University of Alberta, Edmonton, AB, Canada

J.P. Nunes Minho University, Guimaraes, Portugal

S. Parveen School of Engineering, University of Minho, Guimarães, Portugal

L. Pothen Bishop Moore College, Alleppey, Kerala, India

S. Rana School of Engineering, University of Minho, Guimarães, Portugal

C. Scarponi "La Sapienza" University of Rome, Rome, Italy

J.F. Silva Polytechnic Institute of Porto, Porto, Portugal

M.S. Sreekala Sree Sankara College Kalady, Enakulam, Kerala, India

S. Thomas Mahatma Gandhi University, Kottayam, Kerala, India

Z. Wang Hong Kong Polytechnic University, Kowloon, Hong Kong

A. Zulifqar Hong Kong Polytechnic University, Kowloon, Hong Kong 


\section{Woodhead Publishing Series in Composites Science and Engineering}

1 Thermoplastic aromatic polymer composites F. N. Cogswell

2 Design and manufacture of composite structures G. C. Eckold

3 Handbook of polymer composites for engineers Edited by L. C. Hollaway

4 Optimisation of composite structures design A. Miravete

5 Short-fibre polymer composites Edited by S. K. De and J. R. White

6 Flow-induced alignment in composite materials Edited by T. D. Papthanasiou and D. C. Guell

7 Thermoset resins for composites Compiled by Technolex

8 Microstructural characterisation of fibre-reinforced composites Edited by J. Summerscales

9 Composite materials F. L. Matthews and R. D. Rawlings

10 3-D textile reinforcements in composite materials Edited by A. Miravete

11 Pultrusion for engineers Edited by T. Starr

12 Impact behaviour of fibre-reinforced composite materials and structures Edited by S. R. Reid and G. Zhou

13 Finite element modelling of composite materials and structures F. L. Matthews, G. A. O. Davies, D. Hitchings and C. Soutis

14 Mechanical testing of advanced fibre composites Edited by G. M. Hodgkinson

15 Integrated design and manufacture using fibre-reinforced polymeric composites Edited by M. J. Owen and I. A. Jones

16 Fatigue in composites Edited by B. Harris

17 Green composites Edited by C. Baillie

18 Multi-scale modelling of composite material systems Edited by C. Soutis and P. W. R. Beaumont

19 Lightweight ballistic composites Edited by A. Bhatnagar 
20 Polymer nanocomposites

Y.-W. Mai and Z.-Z. Yu

21 Properties and performance of natural-fibre composite

Edited by K. Pickering

22 Ageing of composites

Edited by R. Martin

23 Tribology of natural fiber polymer composites

N. Chand and M. Fahim

24 Wood-polymer composites

Edited by K. O. Niska and M. Sain

25 Delamination behaviour of composites

Edited by S. Sridharan

26 Science and engineering of short fibre reinforced polymer composites S.-Y. Fu, B. Lauke and Y.-M. Mai

27 Failure analysis and fractography of polymer composites

E. S. Greenhalgh

28 Management, recycling and reuse of waste composites

Edited by V. Goodship

29 Materials, design and manufacturing for lightweight vehicles

Edited by P. K. Mallick

30 Fatigue life prediction of composites and composite structures

Edited by A. P. Vassilopoulos

31 Physical properties and applications of polymer nanocomposites

Edited by S. C. Tjong and Y.-W. Mai

32 Creep and fatigue in polymer matrix composites

Edited by R. M. Guedes

33 Interface engineering of natural fibre composites for maximum performance Edited by N. E. Zafeiropoulos

34 Polymer-carbon nanotube composites

Edited by T. McNally and P. Pötschke

35 Non-crimp fabric composites: Manufacturing, properties and applications Edited by S. V. Lomov

36 Composite reinforcements for optimum performance

Edited by P. Boisse

37 Polymer matrix composites and technology

$R$. Wang, S. Zeng and Y. Zeng

38 Composite joints and connections

Edited by P. Camanho and L. Tong

39 Machining technology for composite materials

Edited by H. Hocheng

40 Failure mechanisms in polymer matrix composites

Edited by P. Robinson, E. S. Greenhalgh and S. Pinho

41 Advances in polymer nanocomposites: Types and applications

Edited by F. Gao

42 Manufacturing techniques for polymer matrix composites (PMCs)

Edited by S. Advani and K.-T. Hsiao

43 Non-destructive evaluation (NDE) of polymer matrix composites: Techniques and applications

Edited by V. M. Karbhari 
44 Environmentally friendly polymer nanocomposites: Types, processing and properties

S. S. Ray

45 Advances in ceramic matrix composites

Edited by I. M. Low

46 Ceramic nanocomposites

Edited by R. Banerjee and I. Manna

47 Natural fibre composites: Materials, processes and properties

Edited by A. Hodzic and R. Shanks

48 Residual stresses in composite materials

Edited by M. Shokrieh

49 Health and environmental safety of nanomaterials: Polymer nanocomposites and other materials containing nanoparticles

Edited by J. Njuguna, K. Pielichowski and H. Zhu

50 Polymer composites in the aerospace industry

Edited by P. E. Irving and C. Soutis

51 Biofiber reinforcement in composite materials

Edited by $O$. Faruk and M. Sain

52 Fatigue and fracture of adhesively-bonded composite joints: Behaviour, simulation and modelling

Edited by A. P. Vassilopoulos

53 Fatigue of textile composites

Edited by V. Carvelli and S. V. Lomov

54 Wood composites

Edited by M. P. Ansell

55 Toughening mechanisms in composite materials

Edited by Q. Qin and J. Ye

56 Advances in composites manufacturing and process design

Edited by P. Boisse

57 Structural integrity and durability of advanced composites: Innovative modelling methods and intelligent design

Edited by P.W.R. Beaumont, C. Soutis and A. Hodzic

58 Recent advances in smart self-healing polymers and composites

Edited by G. Li and H. Meng

59 Manufacturing of nanocomposites with engineering plastics

Edited by $V$. Mittal

60 Fillers and reinforcements for advanced nanocomposites

Edited by $Y$. Dong, R. Umer and A. Kin-Tak Lau

61 Biocomposites: Design and mechanical performance

Edited by M. Misra, J. K. Pandey and A. K. Mohanty

62 Numerical modelling of failure in advanced composite materials

Edited by P.P. Camanho and S. R. Hallett

63 Marine applications of advanced fibre-reinforced composites

Edited by J. Graham-Jones and J. Summerscales

64 Smart composite coatings and membranes: Transport, structural, environmental and energy applications

Edited by M. F. Montemor

65 Modelling damage, fatigue and failure of composite materials

Edited by R. Talreja and J. Varna 
66 Advanced fibrous composite materials for ballistic protection Edited by $X$. Chen

67 Lightweight composite structures in transport Edited by J. Njuguna

68 Structural health monitoring (SHM) in aerospace structures Edited by F.-G. Yuan

69 Dynamic deformation and fracture in composite materials and structures Edited by V. Silberschmidt

70 Advanced composite materials for aerospace engineering: Processing, properties and applications

Edited by $S$. Rana and R. Fangueiro

71 Lightweight ballistic composites: Military and law-enforcement applications, 2nd Edition

Edited by A. Bhatnagar 


\section{Editors' biographies}

Dr Sohel Rana is currently a Senior Scientist at Fibrous Materials Research Group, University of Minho, Portugal. He obtained his bachelor's degree in Textile Technology from University of Calcutta, India and a master's degree and $\mathrm{PhD}$ in Fibre Science and Technology from Indian Institute of Technology (IIT, Delhi), India. His current research areas are advanced fibrous and composite materials, natural fibres, nanocomposites, electrospinning, multifunctional and bio-composite materials and so on. He is author of one book, edited four books and contributed 14 book chapters, six keynote and invited papers, and about 100 publications in various refereed journals and international conferences. He has also participated in the editorial board of several scientific journals and is a potential reviewer for numerous scientific journals, including Composite Science and Technology, Composites Part A, Composite Interfaces, Journal of Composite Materials, Journal of Reinforced Plastics and Composites, Powder Technology, Journal of Nanomaterials, Journal of Applied Polymer Science and others.

Prof. Raul Fangueiro is currently professor and senior researcher in the School of Engineering at the University of Minho, Portugal. He is the Head of the Fibrous Materials Research Group of the same university with expertise in advanced materials (nano, smart and composite) and structures (3D, auxetic and multiscale) with 25 researchers. He is the mentor and the coordinator of the Fibrenamics International Platform (www.fibrenamics.com) including 200 partners developing promotion, dissemination, technology transfer and research activities on fibre-based advanced materials. He has more than 110 published papers in international reputed scientific journals, 320 conference publications, 36 books and 14 patents. He is the scientific coordinator of several national and international research projects on advanced fibrous and composite materials, mainly for building, architectural and health care applications. He supervised various $\mathrm{PhD}$ and post-doctoral scientific works, and is an expert of the European Technological Textile Platform and member of the editorial board of several leading international scientific journals on composite and fibrous materials. 
This page intentionally left blank 


\section{Preface}

Currently, the aerospace industry is looking for alternative materials to reduce fuel consumption and improve safety and performance. Fibre-reinforced composites offer a wide range of properties by combining fibres from different materials (eg, polymeric, inorganic or metallic), scales (macro, micro or nano) and forms (tubes, particles, short fibres, tows or fabrics) with various matrix materials. Advanced composite materials can address all the demands asked for in aerospace materials, and, consequently, their use in the aerospace industry is steadily increasing.

This book focusses predominantly on advanced composite materials and their use in aerospace applications. It discusses the basic and advanced requirements of these materials that are necessary for various applications in the aerospace sector. All the main types of commercial composites such as laminates, sandwich composites, braided composites, ceramic and metal matrix composites and carbon-carbon composites are discussed and compared to metals. Various aspects, including the type of fibre, matrix, structure, properties, modelling, testing and mechanical and structural behaviour are discussed. The introductory chapter (chapter: Advanced composites in aerospace engineering) provides brief discussion on the main requirements of the aerospace materials and how advanced composites can fulfil these demands. Also, this chapter introduces different types of composite materials which are already in use or have future prospects in the aerospace industry. Detailed discussions on these various composite materials are presented separately in subsequent chapters.

Besides materials, architecture of reinforcements also has strong influence on the performance of composites. The use of advanced fibrous architectures in composite materials is increasing to address the demands of advanced technical sectors. In consideration of this, chapter "Advanced fibrous architectures for composites in aerospace engineering" has been dedicated to advanced 2D and 3D fibrous structures manufactured by weaving and knitting technologies. Their production methods, properties and applications are discussed in detail.

There are several new types of composite materials that have huge potential for applications in the aerospace sector, such as nanocomposites, and multiscale and auxetic composites; these are also explored in detail. Like other industrial sectors, nanotechnology has also shown huge promise to develop outstanding high-performance and multifunctional materials. Nanocomposites and multiscale composites are such advanced materials with great prospects in the aerospace sector. The concepts, production, processing, challenges, modelling and applications of these composites are presented in chapters "Polymer nanocomposite: an advanced material for aerospace 
applications and Multiscale composites for aerospace engineering". Auxetic composites are also new and show excellent characteristics for considering them in aerospace applications. Details on these composites have been presented in chapter "Auxetic composites in aerospace engineering".

Self-sensing of damage and its automatic healing are essential characteristics which can greatly improve the safety, reduce maintenance and improve performance of aerospace materials. Chapters "Self-sensing structural composites in aerospace engineering and Self-healing composites for aerospace applications" present detailed information on the concept, types, mechanisms and properties of various self-sensing and self-healing composites and their application in aerospace engineering. Looking at the environmental benefits and sustainability, natural fibre and bio-composites can also find potential applications in the aerospace industry, and these important materials are discussed in chapter "Natural fibre and polymer matrix composites and their applications in aerospace engineering".

Quality control is an important task for materials used in aerospace engineering, which demands high safety. Quality control for aerospace materials begins with the inspection of the raw materials and continues through the monitoring of the production process and characterization of the final structural parts. All these essential steps of quality control for aerospace composites are discussed in detail in chapter "Quality control and testing methods for advanced composite materials in aerospace engineering".

The book's main strength is that it covers the design, processing, properties, modelling and application potential of these materials. What sets the book apart from other published titles is that it is completely dedicated to the use of advanced composite materials in aerospace applications. It discusses the overall requirements for these materials, the different types that are currently available, structures, properties, testing, modelling and product design examples. The book discusses all the existing types of advanced composite materials currently available as well as novel materials that are still in the initial stages of research. We strongly believe that this book will be essential reading for engineers and scientists currently working in this field of research as well as students taking selected courses on advanced composite materials.

We are highly indebted to all authors for their excellent efforts and valuable contributions. We also would like to thank the Fibrenamics Research Group and Centre for Textile Science and Technology, University of Minho for providing all the resources required for the preparation of the book. Sincere thanks are also due to our colleagues (especially Mr Subramani Pichandi) for their kind help in the preparation of the artwork and formatting of the book chapters. We also acknowledge the great help and cooperation from the publishing team (Gwen Jones, Steven Mathews, Kate Hardcastle and Charlotte Cockle) of Elsevier Publishing Ltd.

Sohel Rana and Raul Fangueiro

University of Minho 


\section{Sandwiched composites in aerospace engineering}

J.P. Nunes ${ }^{1}$, J.F. Silva ${ }^{2}$

${ }^{1}$ Minho University, Guimaraes, Portugal; ${ }^{2}$ Polytechnic Institute of Porto, Porto, Portugal

\subsection{Introduction}

One of the biggest challenges to the design engineer in the aircraft and space industries is weight reduction. In these markets, each kilogram costs large amounts of money, and sandwiched composites became one of the most efficient solutions to conjugate the highest bending stiffness and strength-to-weight ratios in structural components (Noor, 2000; Marasco, 2005).

Typical sandwich composites consist of two thin, stiff, high-strength facing skins separated by a thick and light core (see Fig. 5.1). The skins are bonded to the core using structural adhesives strong enough to transfer loads between the two faces. The core acts like an I-beam's web, which means taking the shear loads as well as providing structural rigidity by keeping high-strength facing skins away from the neutral axis where the higher tensile and compressive stresses are developed. Sandwich structures differ from the I-beam ones mainly because they have the web spread over the entire cross-section, which provides much higher torsional rigidity than a concentrated middle-section web may offer in an I-beam (Zenkert, 1995; Mazumdar, 2001).

This chapter will review the main raw materials, manufacturing technologies and design methods applied in sandwich composite structures.

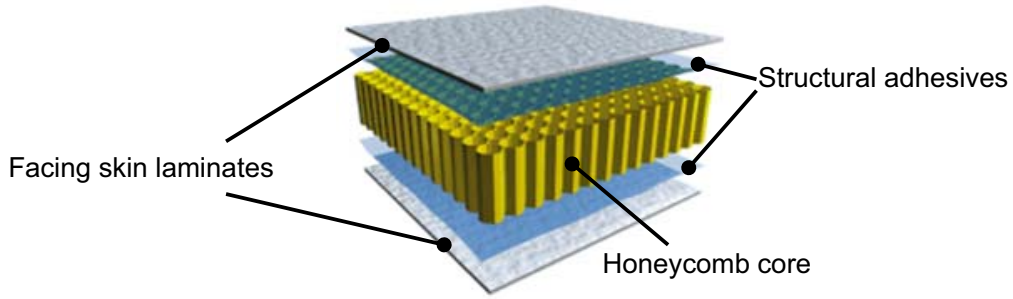

Figure 5.1 Typical sandwich composite panel.

Adapted from Sezgin, F.E., 2011. Mechanical Behavior and Modeling of Honeycomb Cored Laminated Fiber/Polymer Sandwich Structures. Master Thesis, İzmir Institute of Technology, Turkey. 


\subsection{Sandwiched composite structures}

\subsubsection{Raw materials}

The relevant properties of major raw materials used as facing skinks, cores and adhesives in sandwich composite structures for aircraft and aerospace applications are summarized in this section.

\subsubsection{Facing skins}

Facing skins usually consist of polymer matrix-based fibre-reinforced composite laminates. Typical, such laminates are manufactured by using hand lay-up, autoclave, vacuum-assisted resin infusion, compression moulding, resin transfer moulding (RTM) or automated tape-laying technologies to stack polymer-based preimpregnated materials, or prepregs (unidirectional tapes, woven fabrics etc.) (Bitzer, 1997).

The selection of the matrix must be carefully considered in order to achieve the required surface properties (corrosion, temperature behaviour etc.) and manufacturing type of the composite material. Both thermosetting and thermoplastic resins are commonly used as matrices (see Table 5.1).

Epoxy, unsaturated polyester and vinyl ester are the most widely used thermosetting resins. Epoxies are almost always preferred for advanced applications, such as the aerospace and aircraft markets, where lower weight, high strength and dimensional accuracy are much more critical. Epoxies are also tougher, and they present better behaviour to heat distortion and much less shrinkage than unsaturated polyester and vinyl ester resins. Being less expansive, easy to process and superior in corrosion resistance, unsaturated polyester resins are much better adapted to more commercial and less demanding markets. Vinyl esters usually present higher corrosion behaviour than unsaturated polyesters and may be considered an intermediary solution between the epoxies and unsaturated polyesters.

Currently, thermoplastics are applied as matrix in facing-skin laminates. Compared to brittle thermosets, they present higher toughness, ductility and failure strains; enhance the fatigue, corrosion and thermal behaviours (polyetherimide (PEI) and polyetheretherketone (PEEK)); and can be much more easily recycled and reprocessed. However, it is still very difficult and expensive to manufacture stacking laminates using thermoplastic matrices because their processing requires the use of much higher temperatures and pressures. Heated compression moulding and automated tapelaying processing are the major technologies used to produce thermoplastic matrices in facing skins of sandwich composite structures.

Table 5.1 exhibits the main properties of the polymer matrices mostly used in the facing skins of sandwich structural panels. In addition to the mechanical properties, the maximum service temperature is many times the most relevant criterion for selecting the polymer matrix material to be applied in advanced composite structures for aircraft and aerospace applications.

Carbon fibres, due to their extremely low weight, high stiffness and high tensile strength, are by far the most common to be chosen to reinforce facing skin laminates 
Table 5.1 Main polymers used as matrices in sandwich-facing skins

\begin{tabular}{|c|c|c|c|c|}
\hline Material & $\begin{array}{l}\text { Density } \\
\left(\mathbf{M g} / \mathbf{m}^{3}\right)\end{array}$ & $\begin{array}{l}\text { Tensile } \\
\text { modulus } \\
(\mathbf{G P a})\end{array}$ & $\begin{array}{l}\text { Tensile } \\
\text { strength } \\
\text { (MPa) }\end{array}$ & $\begin{array}{l}\text { Maximum } \\
\text { service } \\
\text { temperature } \\
\left({ }^{\circ} \mathrm{C}\right)\end{array}$ \\
\hline \multicolumn{5}{|l|}{ Thermosetting resins } \\
\hline Epoxy & $1.2-1.4$ & $2.5-5$ & $50-130$ & $80-215$ \\
\hline Unsaturated polyester & $1.1-1.4$ & $1.6-4.1$ & $35-95$ & $60-150$ \\
\hline Vinyl ester & $1.1-1.3$ & $3.0-3.5$ & $73-81$ & $60-150$ \\
\hline Phenolic & $1.1-1.4$ & $2.7-4.1$ & $35-60$ & $70-120$ \\
\hline Cyanate esters & $1.1-1.3$ & $2.6-3.5$ & $70-125$ & $150-250$ \\
\hline Bismaleimide & $1.2-1.3$ & $3.9-4.6$ & $120-180$ & $230-320$ \\
\hline \multicolumn{5}{|l|}{ Thermoplastics } \\
\hline Polypropylene (PP) & $0.9-0.91$ & $1.15-1.57$ & $31.0-41.9$ & $50-135$ \\
\hline Polyamide/(nylon) (PA) & $1.12-1.42$ & $0.25-3.84$ & $35.2-167.6$ & $75-150$ \\
\hline Polycarbonate (PC) & 1.20 & $2.20-2.41$ & $62.7-73.3$ & 115 \\
\hline Polysulphone (PSU) & $1.24-1.25$ & $2.51-2.72$ & $60.0-74.7$ & 150 \\
\hline Polyethersulphone (PES) & $1.37-1.46$ & $2.44-2.86$ & $68.3-100.6$ & 180 \\
\hline Polyimide (PI) & $1.33-1.43$ & $2.10-4.02$ & $72.4-119.4$ & 170 \\
\hline Polyphenylene sulphide (PPS) & 1.35 & $3.28-3.42$ & $48.3-87.3$ & $120-220$ \\
\hline Polyetherimide (PEI) & $1.26-1.27$ & $2.72-4.02$ & $62.1-150.2$ & 170 \\
\hline Polyether ether ketone (PEEK) & $1.3-1.32$ & 3.63 & $70.3-104.8$ & $120-250$ \\
\hline
\end{tabular}

Adapted from Mazumdar, S.K., 2001. Composites Manufacturing: Materials, Product and Process Engineering. CRC Press; Muzzy, J.D., 2000. Thermoplastics - properties. In: Kelly, A., Zweben, C. Comprehensive Composite Materials. Vol. 2. Elsevier Ltd, pp. 57-76; Peters, S.K. (Ed.), 1998. Handbook of Composites, second ed. Chapman \& Hall.

of sandwich structures used in aerospace and aircraft applications. Glass and aramid fibres are other reinforcements that may be used as alternatives. Glass fibres may be used in price-competitive parts that require less stiffness due to their much lower cost.

Aramid fibres, which are based on aromatic polyamide precursors and present the lowest density, may be used in facing skin laminates requiring superior wear and impact behaviour due to their excellent toughness and abrasion properties. However, the major limitations to the application of aramid fibres are their much higher price (in comparison to glass fibres), low service temperature, compressive properties and well-known lack of adhesion properties.

The typical properties of the most frequently used reinforcing fibres are shown in Table 5.2. As may be seen, carbon fibres exhibit the highest specific modulus ratio between the tensile modulus and density. 
Table 5.2 Properties of major fibres used as reinforcements in sandwich skins

\begin{tabular}{|l|l|l|l|l|l|l|l|}
\hline Type of fibre & $\begin{array}{l}\text { Density } \\
\left(\mathbf{M g} / \mathbf{m}^{\mathbf{3}}\right)\end{array}$ & $\begin{array}{l}\text { Tensile } \\
\text { modulus }(\boldsymbol{E}) \\
(\mathbf{G P a})\end{array}$ & $\begin{array}{l}\text { Tensile } \\
\text { strength }(\boldsymbol{\sigma}) \\
(\mathbf{M P a})\end{array}$ & $\begin{array}{l}\text { Specific } \\
\text { modulus }(\boldsymbol{E} / \boldsymbol{\rho}) \\
\left(\mathbf{G P a} \mathbf{~ m}^{\mathbf{3}} / \mathbf{M g}\right)\end{array}$ & $\begin{array}{l}\text { Specific } \\
\text { strength }(\boldsymbol{\sigma} / \boldsymbol{\rho}) \\
\left(\mathbf{M P a} \mathbf{~ m}^{\mathbf{3}} / \mathbf{M g}\right)\end{array}$ & $\begin{array}{l}\text { Melting } \\
\mathbf{p o i n t}\left({ }^{\circ} \mathbf{C}\right)\end{array}$ & $\begin{array}{l}\text { Relative } \\
\mathbf{c o s t}\end{array}$ \\
\hline E-glass & 2.54 & 70 & 3450 & 27.6 & 1385 & $\geq 1540$ & Low \\
S-glass & 2.50 & 86 & 4500 & 34.4 & 1800 & 947 & $\geq 1540$ \\
HM-carbon (high modulus) & 1.90 & 400 & 1800 & 210.5 & 1529 & $\geq 3500$ & Moderate \\
HS-carbon (high strength) & 1.70 & 240 & 2600 & 141.2 & 1346 & 2300 \\
Boron & 2.6 & 400 & 3500 & 153.8 & 1931 & High \\
Aramid (Kevlar ${ }^{\circledR}$ 29) & 1.45 & 80 & 2800 & 55.2 & 1931 & High \\
Aramid (Kevlar ${ }^{\circledR}$ 49) & 1.45 & 130 & 2800 & 89.7 & 500 \\
\hline
\end{tabular}

Adapted from Mazumdar, S.K., 2001. Composites Manufacturing: Materials, Product and Process Engineering. CRC Press; Peters, S.K. (Ed.), 1998. Handbook of Composites, second ed. Chapman \& Hall. 
The prepregs, which present the reinforcing fibres already impregnated with the polymer matrix, are commonly used to manufacture composites of sandwich-facing skins for aircraft and aerospace structural components by using the autoclave, compression-moulding or tape-laying technologies.

Thermosetting matrix prepregs must be kept in refrigerators at low temperature to avoid the resin cure completion. In these prepregs, after impregnating the reinforcing fibres with the thermosetting matrix resin, the cure reaction is suspended by keeping the material at below-freezing temperatures. Due to that and contrarily to thermoplastic matrix prepregs, the thermosetting ones always present a limited shelf life. The typical properties of several prepreg materials that can be applied in the facing-skin sandwich composite structures may be seen in Table 5.3, which shows that prepregs can use both unidirectional fibres and woven fabrics.

\subsubsection{Sandwich cores}

While facing-skin laminates should withstand both in-plane and bending (primary loading) efforts in sandwich structures, the core must carry transverse shear loads and the compressive and crashing efforts placed on the panels. The core must also ensure an adequate transfer of loads between the two facing-skin laminates through the structural adhesives used.

Foam, solid and honeycomb cores are relatively inexpensive and may consist of balsa wood, plywood and an almost infinite selection of open- and closed-cell thermoplastic and thermosetting foams, presenting a wide variety of densities and shear moduli, and rigid, flexible or rubbery behaviour (HexWeb; Beckwith, 2008) (see Figs. 5.2 and 5.3).

Honeycomb architectures are widely used in aerospace, aircraft, transportation and marine structural applications, and the two most common types are hexagonal and square-shaped cell structures. They consist of a series of cells, nested together to form panels similar in appearance to the cross-sectional slice of a beehive. In its expanded form, honeycomb is $90-99 \%$ open space. Honeycomb is fire retardant, flexible and lightweight, and it has good impact resistance. It offers the best strength-toweight ratio of the core materials. Honeycomb cores use both metallic and nonmetallic materials.

Aluminium is almost always the only metal used in the manufacture of honeycomb cores. Nonmetallic honeycomb cores may be made from paper or card, for less load-demanding applications, and from aramid $\left(\right.$ Nomex ${ }^{\circledR}$ ), thermoplastic (polycarbonate, polypropylene, polyetherimide etc.) and other materials, such as glass-reinforced polyimide and phenolic composites Figs. 5.4 and 5.5.

Two main methods are used to manufacture honeycomb cores: expansion and corrugation. Expansion is more common, and it is used for making aluminium and aramid $\left(\right.$ Nomex ${ }^{\circledR}$ ) honeycombs. The process consists of stacking together sheets of material in a block form. Before stacking, adhesive nodelines are printed on the sheets to obtain interrupted adhesive bonding. After curing the stack of sheets, slices of appropriate thickness are cut from the block and then expanded to obtain the desired cell size and shape. 
Table 5.3 Properties of prepregs applied in sandwich skins

\begin{tabular}{|c|c|c|c|c|c|c|c|}
\hline Type of prepreg & $\begin{array}{l}\text { Fibre } \\
\text { volume } \\
\text { fraction } \\
(\%)\end{array}$ & $\begin{array}{l}\text { Processing } \\
\text { temperature } \\
\left({ }^{\circ} \mathrm{C}\right)\end{array}$ & $\begin{array}{l}\text { Tensile } \\
\text { modulus } \\
(E)(\text { GPa })\end{array}$ & $\begin{array}{l}\text { Tensile } \\
\text { strength }(\sigma) \\
(\mathrm{MPa})\end{array}$ & $\begin{array}{l}\text { Maximum } \\
\text { service } \\
\text { temperature } \\
\left({ }^{\circ} \mathrm{C}, \text { dry }\right)\end{array}$ & $\begin{array}{l}\text { Shelf life } \\
\left(-17.8^{\circ} \mathrm{C},\right. \\
\text { months })\end{array}$ & $\begin{array}{l}\text { Out time at } \\
\text { room } \\
\text { temperature } \\
\text { (days) }\end{array}$ \\
\hline \multicolumn{8}{|c|}{ Thermosetting matrix prepregs } \\
\hline $\begin{array}{l}\text { Unidirectional carbon (AS4 } \\
\text { T300)-epoxy }\end{array}$ & $55-65$ & 120 & $103-152$ & $1241-2206$ & $85-120$ & $6-12$ & $14-30$ \\
\hline $\begin{array}{l}\text { Unidirectional carbon } \\
\text { (IM7)-epoxy }\end{array}$ & $55-60$ & 120 & $138-172$ & $2206-3034$ & 120 & 12 & 30 \\
\hline $\begin{array}{l}\text { Unidirectional } \\
\text { S2-glass-epoxy }\end{array}$ & $55-63$ & $120-177$ & $41-55$ & $827-1586$ & $85-120$ & 6 & $10-30$ \\
\hline $\begin{array}{l}\text { Unidirectional aramid } \\
\left(\operatorname{Kevlar}^{\mathbb{B}}\right) \text {-epoxy }\end{array}$ & $55-60$ & $120-141$ & 69 & 965 & 85 & 6 & $10-30$ \\
\hline $\begin{array}{l}\text { Unidirectional carbon } \\
\text { (AS4)-bismaleimide }\end{array}$ & $55-62$ & $177-246$ & $103-152$ & $1379-2206$ & $232-316$ & 6 & 25 \\
\hline $\begin{array}{l}\text { Unidirectional carbon } \\
\text { (IM7)-bismaleimide }\end{array}$ & $60-66$ & $177-227$ & $138-172$ & $2620-2758$ & $232-316$ & $6-12$ & 25 \\
\hline $\begin{array}{l}\text { Unidirectional carbon } \\
\text { (IM7)-cyanate ester }\end{array}$ & $55-63$ & $120-177$ & $138-172$ & $690-2723$ & 232 & 6 & 10 \\
\hline $\begin{array}{l}\text { Unidirectional } \\
\text { S2-glass-cyanate ester }\end{array}$ & $55-60$ & $120-177$ & 48 & 1241 & 204 & 6 & 10 \\
\hline $\begin{array}{l}\text { Plain-weave fabric carbon } \\
\text { (AS4)-epoxy }\end{array}$ & $57-63$ & 120 & $55-70$ & $517-855$ & - & 6 & 10 \\
\hline
\end{tabular}




\begin{tabular}{|c|c|c|c|c|c|c|c|}
\hline $\begin{array}{l}\text { Plain-weave woven fabric } \\
\text { aramid }(285 \mathrm{~K}-4 \mathrm{HS})- \\
\text { epoxy }\end{array}$ & 60 & $120-140$ & $30-31$ & 500 & 85 & 6 & $10-30$ \\
\hline $\begin{array}{l}\text { Plain-weave woven fabric } \\
\text { S-2 glass-epoxy }\end{array}$ & $50-55$ & 120 & $20-34.5$ & $552-600$ & 85 & 6 & 10 \\
\hline $\begin{array}{l}\text { Plain-weave woven fabric } \\
\text { glass (7781-8HS)- } \\
\text { phenolic }\end{array}$ & 55 & - & 20 & 400 & - & - & - \\
\hline $\begin{array}{l}\text { Unidirectional carbon } \\
\text { (IM7)-PEEK }\end{array}$ & $57-63$ & 288 & 179 & 2827 & 177 & Unlimited & Unlimited \\
\hline $\begin{array}{l}\text { Unidirectional carbon } \\
\text { (G34/700)-PA (nylon 6) }\end{array}$ & $55-62$ & $232-260$ & 110 & 1489 & 93 & Unlimited & Unlimited \\
\hline $\begin{array}{l}\text { Unidirectional aramid/PA } \\
\text { (nylon 12) }\end{array}$ & 52 & 204 & 47 & 1413 & - & Unlimited & Unlimited \\
\hline $\begin{array}{l}\text { Unidirectional carbon } \\
\text { (AS4)-PPS }\end{array}$ & 64 & $232-271$ & 121 & 1965 & - & Unlimited & Unlimited \\
\hline $\begin{array}{l}\text { Unidirectional carbon } \\
\text { (IM7)-polyimide (PI) }\end{array}$ & 62 & $321-352$ & 172 & 2620 & 204 & Unlimited & Unlimited \\
\hline $\begin{array}{l}\text { Plain weave fabric carbon } \\
\text { HM (T650-35)- } \\
\text { polyimide (PI) }\end{array}$ & $58-62$ & $349-388$ & $69-124$ & $896-1069$ & $260-316$ & 12 & Unlimited \\
\hline
\end{tabular}

Adapted from Mazumdar, S.K., 2001. Composites Manufacturing: Materials, Product and Process Engineering. CRC Press; HexWeb ${ }^{\text {TM }}$ Honeycomb Sandwich Design Technology. Hexcel ${ }^{\circledR}$ Technology Manuals. <http://www.hexcel.com/resources/technology-manuals> (visit on 19.03.15.). 


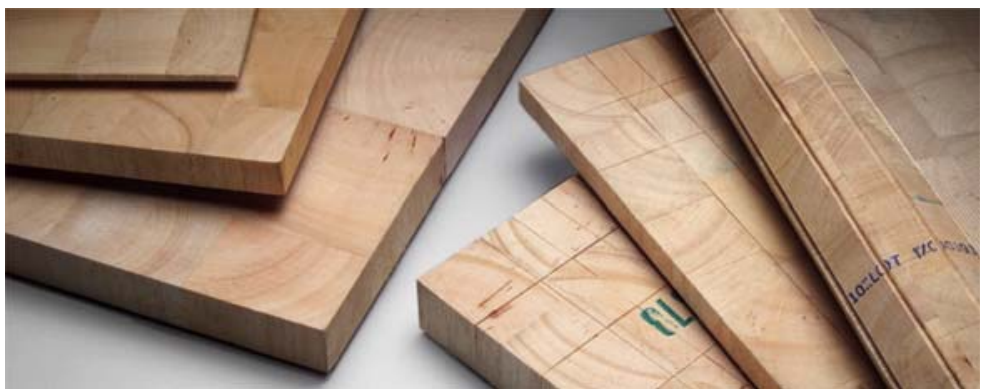

Figure 5.2 Balsa wood core BALTEK ${ }^{\circledR}$ SBC from Airex AG Industries Balsa Wood Core.

(a)

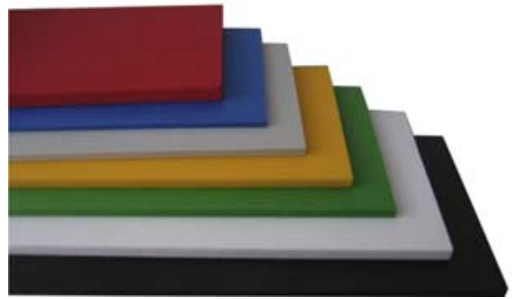

(b)

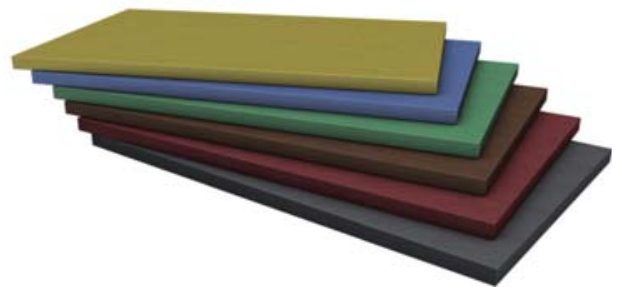

Figure 5.3 Polymer foams: (a) polyvinyl chloride (PVC) foams; (b) polyurethane foams.
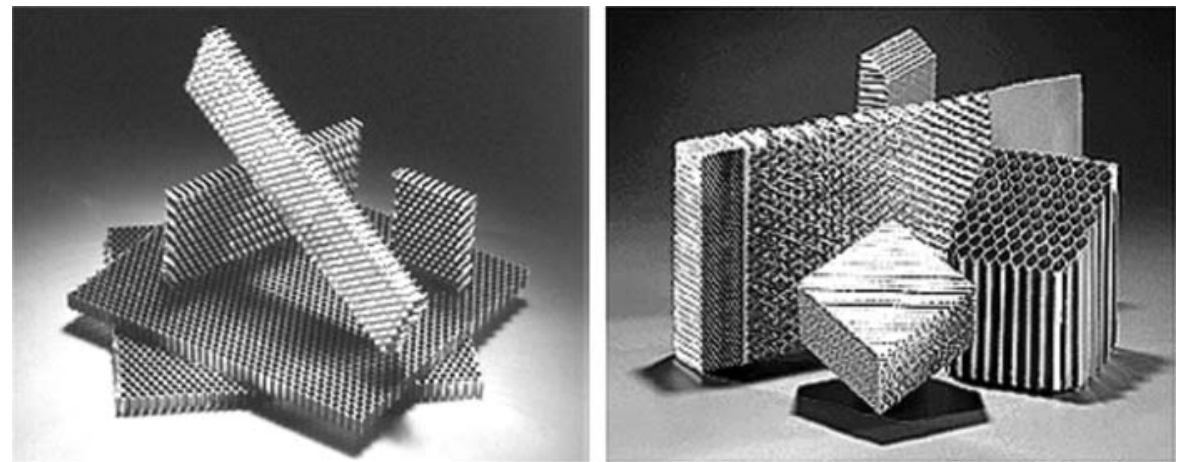

Figure 5.4 Aluminium honeycombs from Alcore Inc. - A Gill Company (Aluminium Honeycombs).

In corrugation, the sheet of material is given a corrugation form by passing through corrugating rolls. The corrugated sheets are then stacked together, bonded and cured. Finally, the honeycomb panels are cut from the block into the desired shape and size without any expansion.

In contrast, the techniques mostly used to manufacture foam cores include gas injection, blowing agents, expandable bead processes and so on. In all these processes, 


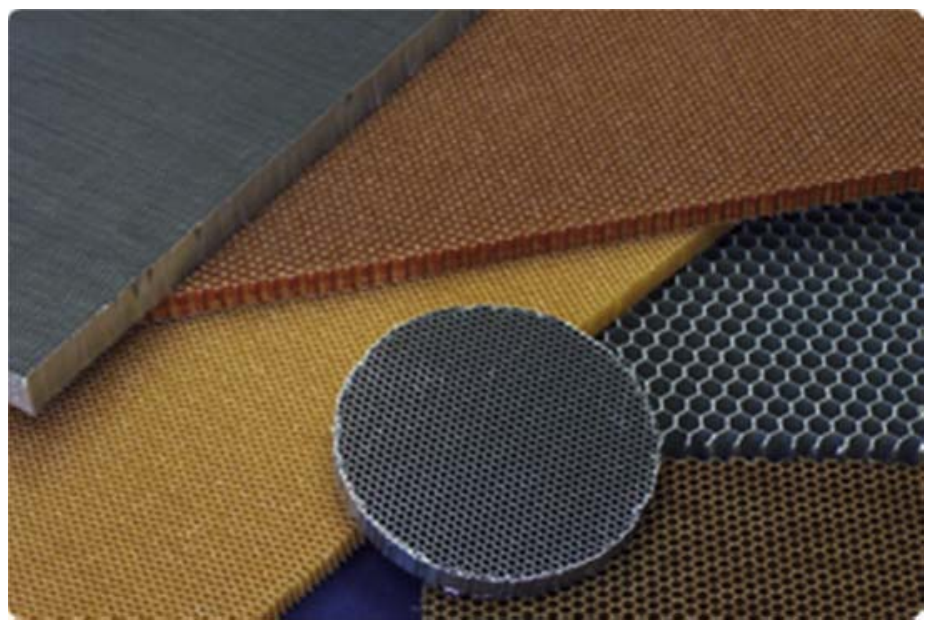

Figure 5.5 Aramid $\left(\operatorname{Nomex}{ }^{\circledR}\right)$ honeycombs.

one gas or blowing agent is supplied to the thermoplastic or thermosetting resins to decrease its density by forming closed or open gaseous cells. The purpose of the foam is to increase the bending stiffness and thickness of the structural sandwich without increasing its weight.

The main properties of several core materials used in composite sandwich structures are summarized in Table 5.4.

\section{Structural adhesives}

The most common structural adhesives used in composite sandwiches are epoxy, acrylic and urethane resins. Typically, they are classified in three categories: (1) two-component mixed adhesives, (2) two-component unmixed adhesives and (3) one-component unmixed adhesives (Mazumdar, 2001).

The majority of epoxy and polyurethane adhesives are two-component mixed adhesives, and the acrylic and anaerobic (urethane methacrylate ester) adhesives fall into the category of two-component unmixed adhesives. The two-component mixed adhesives require the prior mixing of two components before application to the substrate surface. Once the two components are mixed, there is a limited pot life.

In two-component unmixed adhesives, the adhesive is applied on one substrate surface, and an activator, usually in a very small amount, is applied on the other substrate surface. When the two surfaces are put together, the adhesive cures by the reaction between both components.

Finally, one-component unmixed adhesives do not require mixing. Almost all these adhesives consist of a premix of two or more components such as resin, curing agent, fillers and additives. Epoxies, polyurethanes, cyanoacrylates and hot-melt, light-curable and solvent-based adhesives are examples of this type of structural adhesive.

Table 5.5 summarizes some of the main guidelines to allow selecting the appropriate adhesive to be used on a sandwich composite panel for a specific application. 
Table 5.4 Properties of core materials used in sandwich composites

\begin{tabular}{|c|c|c|c|c|c|c|c|}
\hline \multicolumn{2}{|c|}{ Honeycomb density and cell size } & \multirow{2}{*}{\multicolumn{2}{|c|}{$\begin{array}{c}\text { Compressive properties } \\
\text { Stabilized }\end{array}$}} & \multicolumn{4}{|c|}{ Plate shear behaviour } \\
\hline \multirow{2}{*}{$\frac{\text { Density }}{\mathrm{Kg} / \mathrm{m}^{3}}$} & \multirow{2}{*}{$\begin{array}{l}\text { Cell size }^{\mathrm{a}} \\
\mathrm{mm}\end{array}$} & & & \multicolumn{2}{|c|}{ Length direction } & \multicolumn{2}{|c|}{ With direction } \\
\hline & & Strength MPa & Modulus MPa & Strength MPa & Modulus MPa & Strength MPa & Modulus MPa \\
\hline \multicolumn{8}{|c|}{3003 Aluminium } \\
\hline 29 & 19 & 0.9 & 165 & 0.65 & 110 & 0.4 & 55 \\
\hline 37 & 9 & 1.4 & 240 & 0.8 & 190 & 0.45 & 90 \\
\hline 42 & 13 & 1.5 & 275 & 0.9 & 220 & 0.5 & 100 \\
\hline 54 & 6 & 2.5 & 540 & 1.4 & 260 & 0.85 & 130 \\
\hline 59 & 9 & 2.6 & 630 & 1.45 & 280 & 0.9 & 140 \\
\hline 83 & 6 & 4.6 & 1000 & 2.4 & 440 & 1.5 & 220 \\
\hline \multicolumn{8}{|c|}{5052 Aluminium } \\
\hline 37 & 6 & 1.35 & 310 & 0.96 & 220 & 0.58 & 112 \\
\hline 50 & 5 & 2.3 & 517 & 1.45 & 310 & 0.9 & 152 \\
\hline 54 & 6 & 2.6 & 620 & 1.6 & 345 & 1.1 & 166 \\
\hline 72 & 3 & 4.2 & 1034 & 2.3 & 483 & 1.5 & 214 \\
\hline 83 & 6 & 5.2 & 1310 & 2.8 & 565 & 1.8 & 245 \\
\hline 127 & 6 & 10.0 & 2345 & 4.8 & 896 & 2.9 & 364 \\
\hline 130 & 3 & 11.0 & 2414 & 5.0 & 930 & 3.0 & 372 \\
\hline
\end{tabular}




\begin{tabular}{|c|c|c|c|c|c|c|c|}
\hline \multicolumn{8}{|c|}{5056 Aluminium } \\
\hline 37 & 6 & 1.8 & 400 & 1.2 & 220 & 0.7 & 103 \\
\hline 50 & 3 & 2.4 & 669 & 1.7 & 310 & 1.1 & 138 \\
\hline 50 & 5 & 2.8 & 669 & 1.8 & 310 & 1.0 & 138 \\
\hline 72 & 3 & 4.7 & 1275 & 3.0 & 483 & 1.7 & 193 \\
\hline \multicolumn{8}{|c|}{ Aramid HRH10 Nomex ${ }^{\circledR}$} \\
\hline 29 & 3 & 0.9 & 60 & 0.5 & 25 & $\mid 0.35$ & 17.0 \\
\hline 32 & 5 & 1.2 & 75 & 0.7 & 29 & 0.4 & 19.0 \\
\hline 32 & 13 & 1.0 & 75 & 0.75 & 30 & 0.35 & 19.0 \\
\hline 48 & 3 & 2.4 & 138 & 1.25 & 40 & 0.73 & 25.0 \\
\hline 48 & 5 & 2.4 & 140 & 1.2 & 40 & 0.7 & 25.0 \\
\hline 64 & 3 & 3.9 & 190 & 2.0 & 63 & 1.0 & 35.0 \\
\hline 64 & 6 & 5.0 & 190 & 1.55 & 55 & 0.86 & 33.0 \\
\hline 80 & 3 & 5.3 & 250 & 2.25 & 72 & 1.2 & 40.0 \\
\hline 96 & 3 & 7.7 & 400 & 2.6 & 85 & 1.5 & 50.0 \\
\hline 123 & 3 & 11.5 & 500 & 3.0 & 100 & 1.9 & 60.0 \\
\hline 144 & 3 & 15 & 600 & 3.5 & 115 & 1.9 & 60.0 \\
\hline 29 & $5 \mathrm{OX}$ & 1.0 & 50 & 0.4 & 14 & 0.4 & 21.0 \\
\hline 48 & $5 \mathrm{OX}$ & 2.9 & 120 & 0.8 & 20 & 0.85 & 35.0 \\
\hline \multicolumn{8}{|c|}{ Polycarbonate (PC) } \\
\hline 127 & 3 & 4.8 & 379 & - & - & - & - \\
\hline 48 & 6 & 0.8 & 103 & - & - & - & - \\
\hline
\end{tabular}


Table 5.4 Continued

\begin{tabular}{|c|c|c|c|c|c|c|c|}
\hline \multicolumn{2}{|c|}{ Honeycomb density and cell size } & \multirow{2}{*}{\multicolumn{2}{|c|}{$\begin{array}{c}\text { Compressive properties } \\
\text { Stabilized }\end{array}$}} & \multicolumn{4}{|c|}{ Plate shear behaviour } \\
\hline \multirow{2}{*}{$\frac{\text { Density }}{\mathrm{Kg} / \mathrm{m}^{3}}$} & \multirow{2}{*}{$\begin{array}{l}\text { Cell size }^{\mathrm{a}} \\
\mathrm{mm}\end{array}$} & & & \multicolumn{2}{|c|}{ Length direction } & \multicolumn{2}{|c|}{ With direction } \\
\hline & & Strength MPa & Modulus MPa & Strength MPa & Modulus MPa & Strength MPa & Modulus MPa \\
\hline \multicolumn{8}{|c|}{ Polyetherimide (PEI) } \\
\hline $60-110$ & $1-$ & I $0.8-16$ & | $160-290$ & | $0.8-1.4$ & I $18-30$ & I $0.8-1.4$ & I $18-30$ \\
\hline \multicolumn{8}{|c|}{ Glass-reinforced polyimide } \\
\hline 128 & 15 & 19.0 & | 869 & $1-$ & $1-$ & $1-$ & $1-$ \\
\hline \multicolumn{8}{|c|}{ Glass-reinforced phenolic } \\
\hline 64.1 & 5 & 3.3 & - & 1.45 & 79.3 & 0.76 & 34.5 \\
\hline 88 & 5 & $5.2-6.5$ & 655 & 2.55 & 134.5 & 1.31 & 58.6 \\
\hline 56.1 & 6 & 2.8 & - & 1.2 & 62 & 0.69 & 24 \\
\hline 72 & 6 & 3.9 & - & 1.7 & 96.5 & 0.97 & 41.4 \\
\hline \multicolumn{8}{|c|}{ Paper honeycomb } \\
\hline 80 & 6 & 2.8 & - & 1.3 & 208 & 0.57 & 45 \\
\hline 35 & 12.7 & 0.97 & - & 0.54 & 82 & 0.28 & 30.3 \\
\hline \multicolumn{8}{|c|}{ thead1Phenolic foam (Gillfoam ${ }^{\circledR}$ ) } \\
\hline 112 & $1-$ & 1.3 & - & 0.71 & 24.8 & 0.71 & 24.8 \\
\hline 160 & - & 2.3 & - & 1.1 & 44.1 & 1.1 & 44.1 \\
\hline 288 & - & 8.7 & - & 2.2 & 65.5 & 2.2 & 65.5 \\
\hline
\end{tabular}




\section{Polyurethane foam}

\begin{tabular}{l|l}
32 & - \\
64 & - \\
96 & - \\
320 & -
\end{tabular}

$\mid \begin{aligned} & 0.19 \\ & 0.55 \\ & 0.97 \\ & 5.9\end{aligned}$

$\mid \begin{gathered}- \\ - \\ -\end{gathered}$

$\mid \begin{aligned} & 0.14 \\ & 0.33 \\ & 0.62 \\ & 3.1\end{aligned}$

$\mid \begin{aligned} & 1.6 \\ & 5.2 \\ & 10.3 \\ & 103\end{aligned}$

$\mid \begin{aligned} & 0.14 \\ & 0.33 \\ & 0.62 \\ & 3.1\end{aligned}$

\begin{tabular}{l|l}
1.6 \\
5.2 \\
10.3 \\
103
\end{tabular}

PVC foam, closed cell

56

99

400

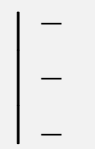

\begin{tabular}{l|l}
0.76 \\
1.4 \\
5.8
\end{tabular}

$\mid$

$\mid \begin{aligned} & 0.53 \\ & 0.83 \\ & 4.5\end{aligned}$

$\mid \begin{gathered}12.4 \\ 15.2 \\ 108\end{gathered}$

$\mid \begin{aligned} & 0.53 \\ & 0.83 \\ & 4.5\end{aligned}$

\begin{tabular}{c|c}
12.4 \\
15.2 \\
108
\end{tabular}

Balsa wood end grain

96

152

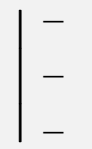

5.2
10.3
26.6

$\mid \begin{aligned} & - \\ & -\end{aligned}$

\begin{tabular}{l|l}
0.97 \\
1.5 \\
4.9
\end{tabular}

$\mid \begin{aligned} & 110 \\ & 193 \\ & 312\end{aligned}$

$\mid \begin{aligned} & 0.97 \\ & 1.5 \\ & 4.9\end{aligned}$

110
193
312

Polystyrene (PS) foam

$30-60$

I -

| $0.3-0.9 \quad$

| $0.25-0.60$

| $4.5-20$

| $0.25-0.60$

| $4.5-20$

Polymethacrylimide (PMI) foam

\begin{tabular}{|c|c|c|c|c|c|c|c|}
\hline $30-300$ & $1-$ & | $0.8-16$ & $1-$ & $0.8-7.5$ & I 19-290 & I $0.8-7.5$ & | 19-290 \\
\hline \multicolumn{8}{|c|}{ Epoxy foam } \\
\hline $80-320$ & $1-$ & $0.62-7.4$ & $1-$ & $0.45-5.2$ & $1-$ & $0.45-5.2$ & $1-$ \\
\hline \multicolumn{8}{|c|}{ Carbon-graphite foam } \\
\hline $30-560$ & $1-$ & $0.2-60$ & $1-$ & $0.05-3.9$ & $1-$ & $0.05-3.9$ & $1-$ \\
\hline
\end{tabular}

${ }^{\mathrm{a}}$ Cell size has imperial units, and presented metric values must be considered approximated.

Adapted from Mazumdar, S.K., 2001. Composites Manufacturing: Materials, Product and Process Engineering. CRC Press; HexWeb ${ }^{\text {TM }}$ Honeycomb Sandwich Design Technology. Hexcel ${ }^{\circledR}$ Technology Manuals. <http://www.hexcel.com/resources/technology-manuals> (visit on 19.03.15.); Beckwith, S.W., July/August 2008. Sandwich core materials \& technologies - Part I. SAMPE Journal 44 (4); Doorway, M.C.G., 1997. Simplified Sandwich Panel Design 34 (3), M.C. Gill Corp. 
Table 5.5 Adhesive selection guidelines

\begin{tabular}{|c|c|c|c|c|c|}
\hline Characteristics & $\begin{array}{l}\text { Standard } \\
\text { epoxies }\end{array}$ & Urethane & Acrylic & Silicones & $\begin{array}{l}\text { Polyolefins } \\
\text { (vinylics) }\end{array}$ \\
\hline Adhesive type ${ }^{a}$ & $\mathrm{~L} 1, \mathrm{~L} 2, \mathrm{~F}$ & $\mathrm{~L}, \mathrm{~W}, \mathrm{HM}$ & $\mathrm{L} 1, \mathrm{~L} 2, \mathrm{~W}$ & L1, L2 & $\mathrm{F}$ \\
\hline $\begin{array}{l}\text { Cure } \\
\text { requirement }\end{array}$ & $\begin{array}{l}\text { Heat, } \\
\text { ambient }\end{array}$ & $\begin{array}{l}\text { Heat, } \\
\text { ambient }\end{array}$ & $\begin{array}{l}\text { Heat, } \\
\text { ambient }\end{array}$ & $\begin{array}{l}\text { Heat, } \\
\text { ambient }\end{array}$ & Hot melt \\
\hline Curing speed & Poor & Very good & Best & Fair & Very good \\
\hline $\begin{array}{l}\text { Substrate } \\
\text { flexibility }\end{array}$ & Very good & Very good & Good & Good & Fair \\
\hline Shear strength & Best & Fair & Good & Poor & Poor \\
\hline Peel strength & Poor to fair & Very good & Good & Very good & Fair \\
\hline $\begin{array}{l}\text { Impact } \\
\text { resistance }\end{array}$ & Fair & Very good & Fair & Best & Fair \\
\hline $\begin{array}{l}\text { Humidity } \\
\text { behaviour }\end{array}$ & Poor & Fair & Fair & Best & Fair \\
\hline $\begin{array}{l}\text { Chemical } \\
\text { resistance }\end{array}$ & Very good & Fair & Fair & Fair & Good \\
\hline $\begin{array}{c}\text { Temperature } \\
\text { resistance }\end{array}$ & Fair & Fair & Fair & Good & Poor \\
\hline Gap filling & Fair & Very good & Very good & Best & Fair \\
\hline $\begin{array}{l}\text { Storage } \\
\text { (months) }\end{array}$ & 6 & 6 & 6 & 6 & 12 \\
\hline
\end{tabular}

${ }^{a}$ Adhesive type: $\mathrm{L} 1=$ Liquid one part; $\mathrm{L} 2=$ Liquid two part; F = Film; W = Waterborne; HM = Hot melt. Adapted from Mazumdar, S.K., 2001. Composites Manufacturing: Materials, Product and Process Engineering. CRC Press.

\subsubsection{Production methods}

As mentioned in Section 5.2.1, expansion and corrugation as well as gas injection, blowing agents and expandable bead processes in the case of foamed materials are the most commonly used processes to manufacture sandwich cores.

Concerning the production of final structural sandwich composite parts, there are two main possibilities: the conventional manufacturing of a composite sandwich is achieved by adhesive joining separately prepared skins to cores. The joining process during sandwich fabrication can require strict quality control. The joining process can be eliminated when the sandwich structures are manufactured by a co-cure method inside a mould. With this method, the sandwich panel adhesive and composite materials are cured simultaneously.

The most widely used production technologies include: vacuum bagging and autoclave, liquid moulding technologies (RTM, structural reaction injection moulding (S-RIM) and infusion), compression moulding, filament winding, wet lay-up and adhesive bonding. From an economical point of view, the continuous lamination manufacturing process is naturally preferable. 


\subsubsection{Liquid moulding technologies}

The liquid moulding technologies include RTM, S-RIM and vacuum-injection moulding technologies, also known as infusion technologies. All these technologies are based on placing the reinforcements in the mould without any resin that is infused into the reinforcement fabrics by using pressure or vacuum. Using closed moulds, the liquid moulding technologies avoid much of closed moulds' styrene emissions problems and are suitable for producing complex shapes. In RTM, the reinforcement fabrics or mats, core materials and eventual inserts are conveniently placed in the mould that is then closed. Afterwards, the resin system is pressurized, using an injection machine that pumps and mixes in the right proportions the resin and catalysts, until full impregnation is obtained (see Fig. 5.6). The impregnation time must be lower than the resin gel-time. RTM relies on the mouldclamping structure being stiff enough to withstand the pressure of the injected resin without opening or distorting the mould. This aspect of the process can become problematic if large-scale components are moulded, with tooling sometimes becoming uneconomic simply due to its handling and clamping requirements.

Vacuum infusion (Fig. 5.7) is a wet lay-up process that is typically used to manufacture composite laminates where reinforcements are impregnated by thermosetting liquid resins. The resin sucked by vacuum is introduced into the mould, being also the bag compacted down against the laminate.

First, the reinforcement fabric layers and core are dried, laid up and precisely positioned in the mould. This may be performed manually or by automation (using robots). Next, when the resin is sucked into the mould, as the laminate is already compacted there is no room for excess resin. As very high resin-to-fibre ratios are obtained in the vacuum infusion process, high mechanical properties are usually obtained in the final composite laminate. Vacuum infusion is suitable for moulding very large structures and is considered a low-volume moulding process.

The mould may be gel-coated in the traditional fashion. After the gel coat cures, the dry reinforcement is positioned in the mould. This includes all the plies of the laminate

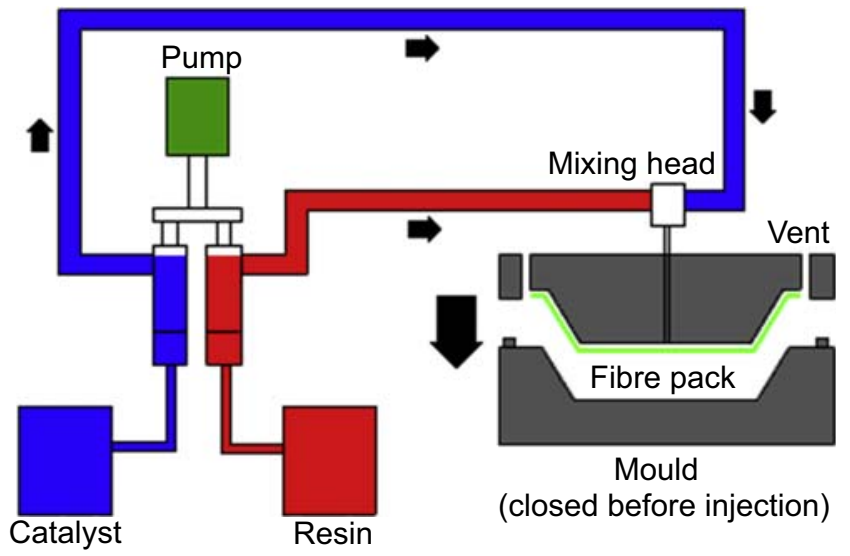

Figure 5.6 Resin transfer moulding (RTM) (Advanced Composite Manufacturing Centre). 


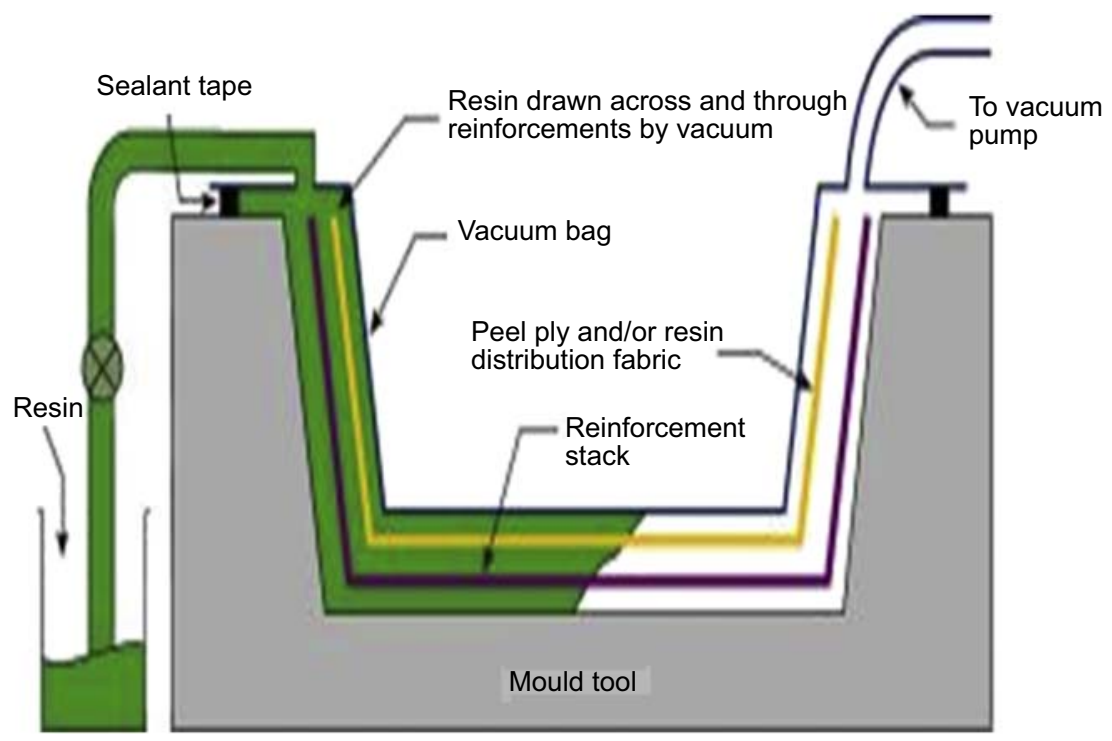

Figure 5.7 Vacuum infusion (van Paepegem).

and core material if required. A perforated release film is placed over the dry reinforcement. Next, a flow medium consisting of a coarse mesh or a 'crinkle' ply is positioned, and perforated tubing is positioned as a manifold to distribute resin across the laminate. The vacuum bag is then positioned and sealed at the mould perimeter. A tube is connected between the vacuum bag and the resin container. A vacuum is applied to consolidate the laminate, and the resin is pulled into the mould. In RTM and vacuum injection moulding, conventional resin systems also used in the wet lay-up process are used. In contrast, S-RIM employs highly reactive resins that are mixed right before injection. Also, RTM and S-RIM technologies use matched moulds, whereas vacuum infusion employs a one-side mould that can sometimes be seen as a modified version of the wet lay-up technology with the mould covered by a vacuum bag to reduce the composite voids content. The filling of resin time of RTM and vacuum infusion is in the range of a few minutes to a few hours, enabling the production of large components before increasing resin viscosity prohibits further impregnation. In the S-RIM technology, the resin filling time is usually less than a minute due to the much higher resin reactivity, meaning that only smaller components than those used with the other two processes can be produced. The component extraction time (demoulding) can vary from a few minutes to hours in the case of RTM, a few hours if vacuum infusion is considered and only a few minutes in the case of S-RIM. In S-RIM, the two-component resin is mixed right before injection in an impingement-mixing nozzle using dedicated pumps. In all processes, multiple inlet points may be necessary for large-component production.

\subsubsection{Bagging and autoclaving}

High-performance composite materials are conventionally processed in autoclaves which require high capital investment for the equipment. The equipment cost increases 


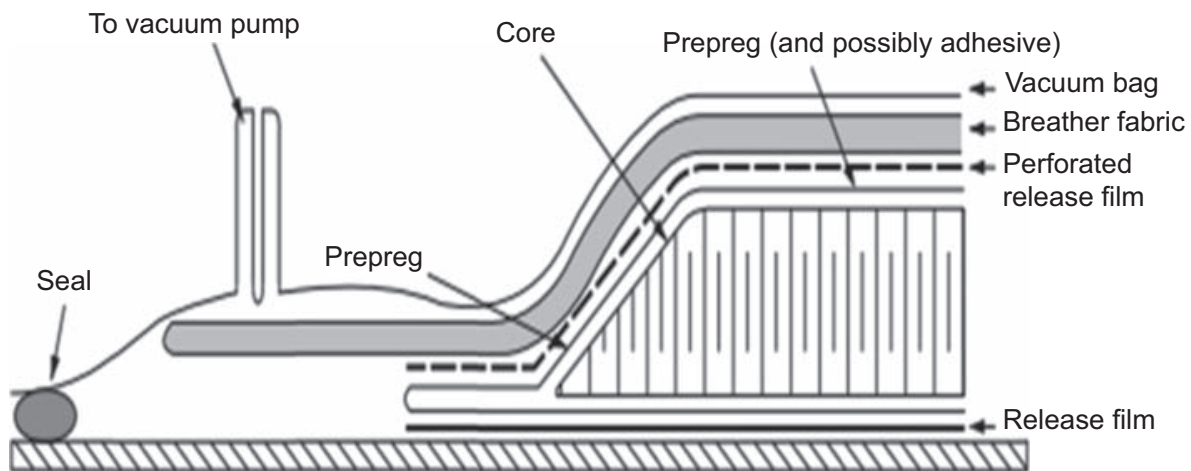

Figure 5.8 Vacuum bag lay-up example (Hexply).

exponentially with the size of the autoclave, which is one of the main constraints on the ability to fabricate large composite structures. Both monolithic laminates and sandwich structures are usually laid up using prepregs. The use of prepregs ensures good impregnation, and resins used in prepregs also tend to have better properties than the ones available for wet lay-up. Sandwich constructions can be manufactured by autoclave or vacuum bag moulding. For autoclave processing, sandwich constructions can usually be laid up and cured as a single-shot process. However, for the vacuum bag curing of large components, it may be necessary to lay up and cure in two or more stages. When using autoclave, the use of excessive pressures can led to eventual core crush.

The vacuum bag technique involves placing and sealing a flexible bag over a composite lay-up (see Fig. 5.8), evacuating all the air from under the bag. The removal of air forces the bag down onto the lay-up with a consolidation pressure of up to $1 \mathrm{~atm}$. The completed assembly, with vacuum still applied, is placed inside an oven or on a heated mould, and the composite is produced after applying an appropriate temperature curing cycle.

Autoclave processing is used for the manufacture of high-quality structural components containing high fibre volume and low void contents. The autoclave technique requires a similar vacuum bag (Fig. 5.8), but the oven is replaced by an autoclave (Fig. 5.9). It allows the application of atmospheric pressure and provides the curing conditions for the composite where the application of vacuum, pressure, heat-up rate and cure temperature are controlled. Typically, high processing pressures are used for thick sections of complex shapes and lower pressures are applied for the production of sandwich structures. The curing cycle can be very long if slow heat-up rates are required to guarantee even temperature distribution on the tooling and composite components.

Manufacturing of sandwich structures made from prepregs may be accomplished in two manners. In some cases, the laminate may be laid directly onto the core in a way similar to that used in wet hand lay-up. Alternatively, previous manufactured skin laminates may be adhesively bonded to the core in a separate process. Sandwich composites manufactured using prepreg lay-up are characterized by good to excellent mechanical properties, low void contents in the laminates skins and consistent laminate quality. 


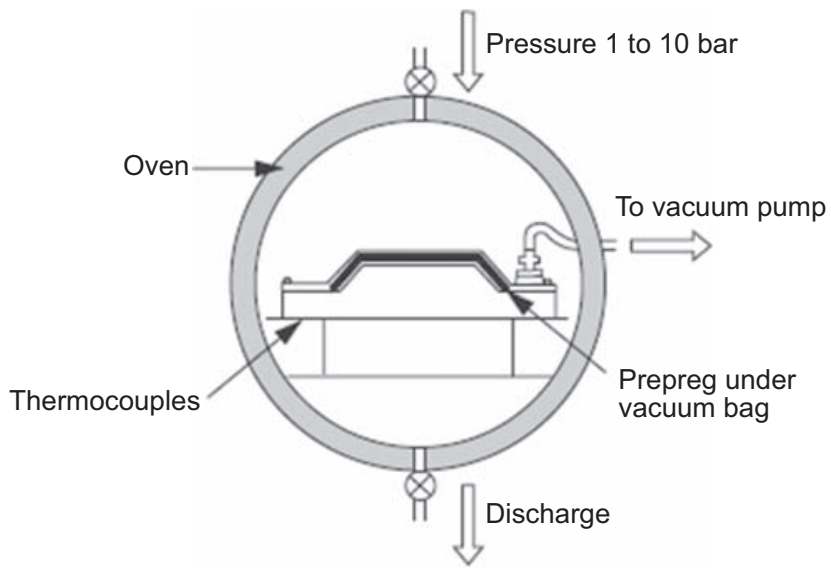

Figure 5.9 Autoclave process (Hexply).

\subsubsection{Compression moulding}

The compression-moulding technology used to manufacture sandwich structures is similar to the one used in the production of monolithic composites. If thermoplastic skins are to be used, the process starts by preheating the skins in an oven and, immediately after, placing them in a cooled mould with the core sandwiched in between. The mould must be closed fast (this requirement is essential) and pressure applied, forcing the skins to bond to the core and allowing a good surface finishing. The core material must withstand the moulding pressure and, if it is of thermoplastic nature, may further enhance bonding since heating of the face sheets will cause the core surface to melt.

This technology can be used to promote the bonding of thermosetting skins to a core panel, obtaining sandwich panels of good quality.

\subsubsection{Wet lay-up}

This is the oldest and one of the most flexible technologies for processing composites and sandwich components with composite. The wet lay-up may be performed either by hand lay-up or spray-up using labour-intensive work. This technology uses a single-side mould, which is first covered by a mould release agent. Usually, a gel coat is deposited directly onto the mould, allowing the laminate to have good environmental resistance and producing a smooth, cosmetically appealing surface. Next, the reinforcements in the form of mats (woven, knitted, stitched or bonded fabrics) are impregnated by hand with resin, with the help of brushed or nip-roller-type impregnators, for forcing the resin into the reinforcements. In the case of spray-up, fibre is chopped in a handheld gun and fed into a spray of catalysed resin directed at the mould. Laminates can cure at atmospheric conditions or with the help of vacuum bagging. The main differences between hand laid-up and sprayed-up composites are due to the differences in labour costs and mechanical properties. The lower labour 
costs of spray-up implies that longer series are economically feasible, and the inferior mechanical properties achieved mean that this approach is used more commonly for commodity-type products.

\subsubsection{Filament winding}

Filament winding is a fabrication technique involving wrapping pretensioned, resin-saturated continuous reinforcements around a rotating symmetrical mould (Fig. 5.10). By changing the rotational velocity of the mandrel with the linear velocity of the guiding system, different fibre patterns can be obtained allowing the control of specific mechanical properties of the obtained composite structure. Recent filament winding equipment always uses computerized numerical control systems that can control up to six axes. Existing software can adjust all settings such as wind angle, fibre bandwidth and desired laminate thickness.

The filament winding of a sandwich structure, usually a circular pipe, begins by producing the filament-wound inner shell face and then stopping the equipment until a flexible or prefoamed core is applied to the produced skin. Then, the machine is restarted and the outer skin is produced.

\subsubsection{Adhesive bonding}

Using the bonding technique, adhesive layers are interleaved between the faces and the core, and the whole stack is subjected to a temperature and pressure cycle, depending on the adhesive resin used. For demanding applications, pressure is applied using vacuum bagging and autoclave, whereas for current applications only vacuum bagging will be enough. Hydraulic presses can also be used for pressure application in adhesive bonding. Laminate skins for bonding are normally produced using 'peel ply' fabric that is removed before bonding, ensuring a proper rugged surface. Also, it is normally necessary to prepare the surfaces to be bonded. Depending on the substrate, surfaces are prepared by one of the following procedures: (1) degrease; (2) degrease, abrade and remove loose particles; or (3) degrease and chemically pretreat. The processing sequence normally involves removing peel ply from the composite skins, preparing surfaces, applying adhesive film and placing the core material between the skins.

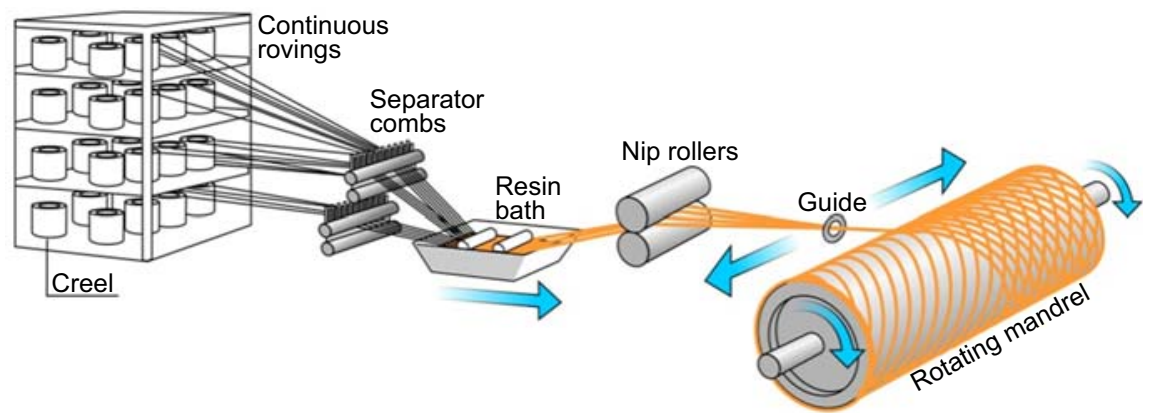

Figure 5.10 Filament winding (Nuplex). 
Then, using vacuum bagging and an autoclave or an oven, apply the specified vacuum, pressure and temperature cycles. The adhesives can be used in film or liquid form, depending on the application, and are usually epoxy or polyurethane. Sandwich components manufacturing through adhesive bonding is characterized by good to excellent mechanical properties.

\subsubsection{Continuous lamination}

Continuous lamination is generally used for the large-scale manufacture of long production runs with a standard design. Sandwich panels made by continuous lamination are manufactured by bonding steel, aluminium or composite foil skins to polyurethane or polystyrene foam, mineral wool or other insulating cores. Recent continuous panel laminators or double-belt laminators have been designed to increase production speed, allowing heating and cooling of the material while at the same time subjecting it to a specified pressure. Two rolls of face sheets are first uncoiled and guided in between the belts of the press. The core is then inserted between the face sheets together with the adhesive layer. The bonding of the skins to the core material is achieved by applying convenient heating and cooling temperatures and pressure values. At the final stage, the panels will be cut at the desired lengths. The core materials can be fed in discrete blocks or, alternatively, in a continuous way by placing in situ core foam in between the skins, through injection and subsequent expansion. Another possibility is to sandwich a thermoplastic polymer film containing a foaming agent between the skins. As the polymer film melts, the foaming agent is free to expand, filling the gap between the face skins with a core foam.

\subsubsection{Composite sandwich properties}

Tables 5.6-5.9 present main basic, physical and mechanical properties of selected composite sandwich panels used by some major aircraft industries. Some of the characteristics presented were determined by those industries' own testing methods.

\subsubsection{Major applications}

Table 5.10 presents typical applications of sandwich composites in major markets.

Figs. 5.11-5.13 also show examples of applications of sandwich composites in satellites and the aerospace, aeronautical and naval industries. In satellites, Fig. 5.11 presents: (1) solar panels: carbon-epoxy prepregs as skins, aluminium honeycomb and film adhesive; (2) antenna reflectors: aramid-epoxy and carbon-cyanate prepregs in the skins and aramid-aluminium honeycomb; and (3) satellite structure: carbonepoxy prepreg, aluminium honeycomb and film adhesive.

The following applications in the aerospace industry may be seen in Fig. 5.12(a): (1) carbon-epoxy prepregs, aluminium honeycomb and adhesives in fairings; (2) the external payload carrier assembly (Speltra); (3) carbon-epoxy prepreg in the EPS ring; (4) front skirt; (5) glass-epoxy and nonmetallic honeycomb in the booster capotage; 
Table 5.6 Basic properties of sandwich panels used by Boeing and Douglas aircraft

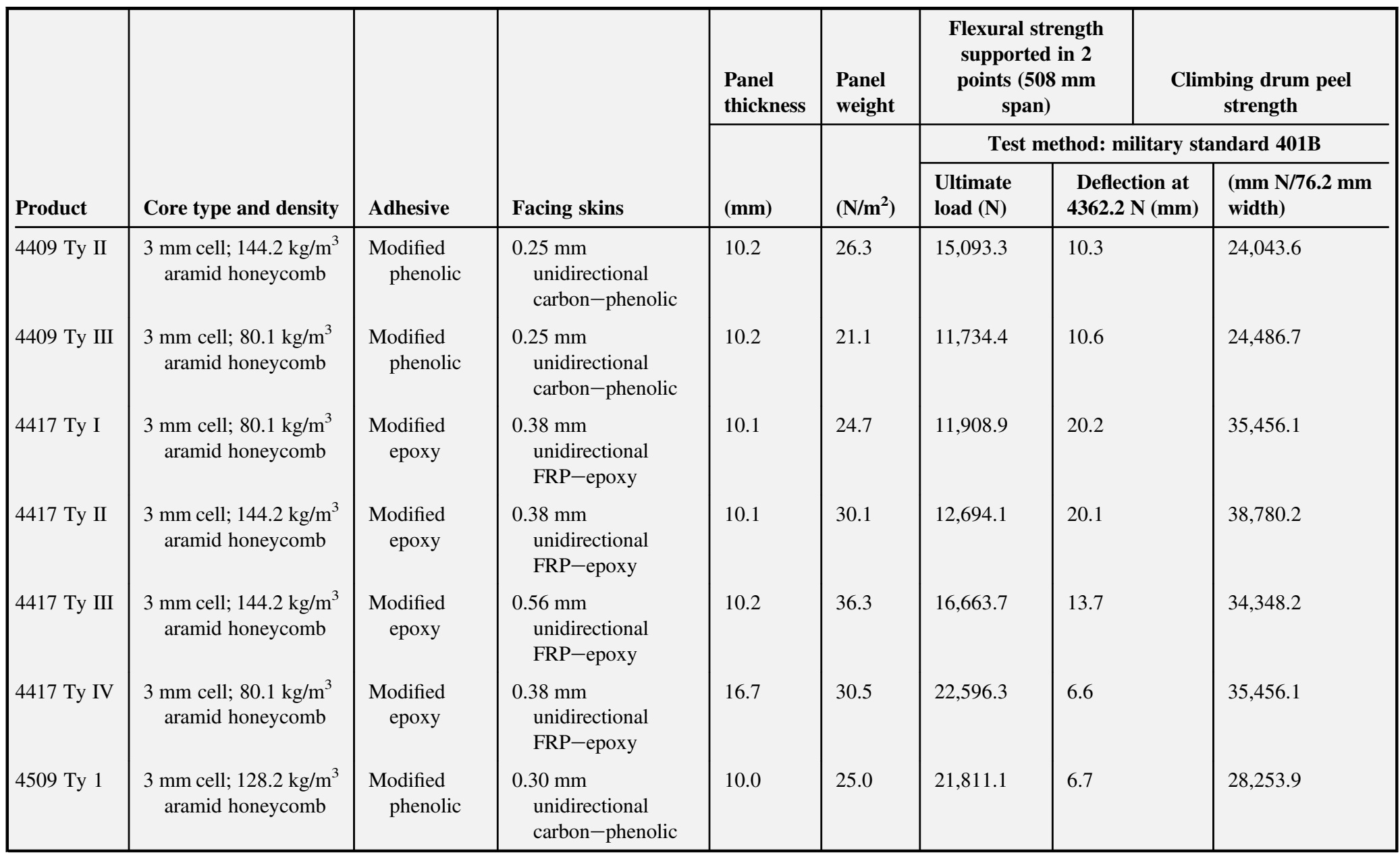




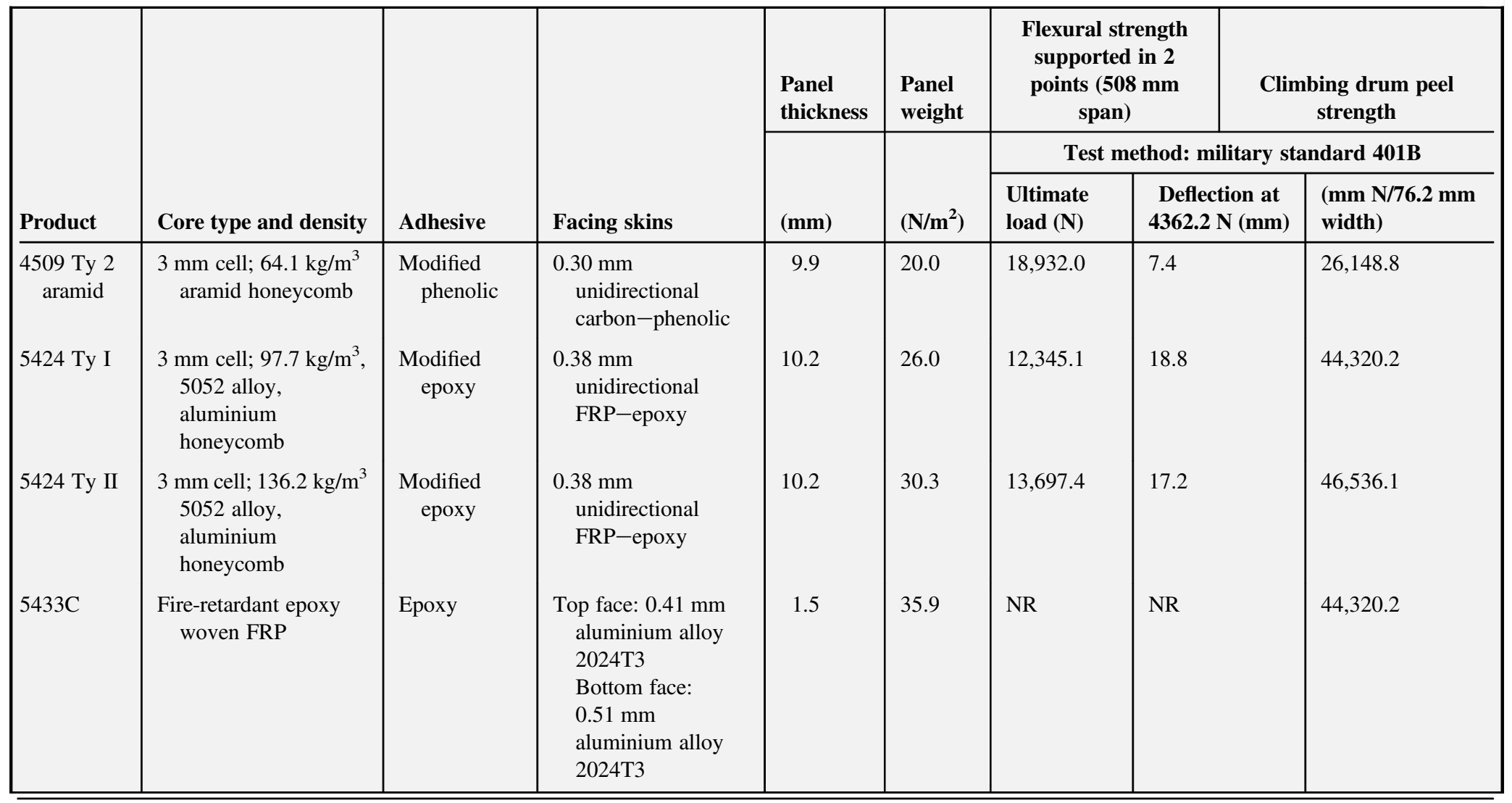

$F R P$, fibreglass-reinforced plastic; $N R$, not required by customer specification.

Adapted from Doorway, M.C.G., 1997. Simplified Sandwich Panel Design. 34 (3), M.C. Gill Corp. 
Table 5.7 Basic properties of sandwich panels used by Airbus Industry aircraft

\begin{tabular}{|c|c|c|c|c|c|c|c|c|c|c|}
\hline \multirow[b]{3}{*}{ Product } & \multirow[b]{3}{*}{$\begin{array}{l}\text { Core type and } \\
\text { density }\end{array}$} & \multirow[b]{3}{*}{ Adhesive } & \multirow[b]{3}{*}{ Facing skins } & \multirow{3}{*}{$\begin{array}{l}\begin{array}{l}\text { Panel } \\
\text { thickness }\end{array} \\
(\mathrm{mm})\end{array}$} & \multirow{3}{*}{$\begin{array}{l}\begin{array}{l}\text { Panel } \\
\text { weight }\end{array} \\
\\
\left(\mathrm{N} / \mathrm{m}^{2}\right)\end{array}$} & \multicolumn{3}{|c|}{ Distributed surface load (N) } & $\begin{array}{l}\text { Concentrated } \\
\text { load without } \\
\text { permanent } \\
\text { deformation }\end{array}$ & $\begin{array}{l}\text { Impact } \\
\text { strength }\end{array}$ \\
\hline & & & & & & \multicolumn{5}{|c|}{$\begin{array}{l}\text { Airbus Industrie TL } 63 / 5000 / 79 \text { (Gillfab 4105) and DAA/MBB } \\
\text { A1 5360 M16 000100 (Gillfab 4205, 4322 and 4323) }\end{array}$} \\
\hline & & & & & & $\begin{array}{l}\text { Load at } \\
10.9 \mathrm{~mm} \\
\text { deflection }\end{array}$ & $\begin{array}{l}\text { Load at } \\
17.0 \mathrm{~mm} \\
\text { deflection }\end{array}$ & $\begin{array}{l}\text { Ultimate } \\
\text { load }\end{array}$ & $(\mathbf{N})$ & $(\mathbf{N} \mathbf{~ m})$ \\
\hline 4105 & $\begin{array}{l}4.8 \mathrm{~mm} \text { cell; } \\
96.1 \mathrm{~kg} / \mathrm{m}^{3} \\
\text { aramid } \\
\text { honeycomb }\end{array}$ & $\begin{array}{c}\text { Modified } \\
\text { epoxy }\end{array}$ & $\begin{array}{l}0.64 \mathrm{~mm} \text { woven } \\
\text { FRP epoxy }\end{array}$ & 9.5 & 32.4 & NA & NA & 218,111 & $>8724.4$ & NA \\
\hline 4205 & $\begin{array}{l}4.8 \mathrm{~mm} \text { cell; } \\
96.1 \mathrm{~kg} / \mathrm{m}^{3} \\
\text { aramid } \\
\text { honeycomb }\end{array}$ & $\begin{array}{c}\text { Modified } \\
\text { epoxy }\end{array}$ & $\begin{array}{l}0.64 \mathrm{~mm} \text { fibreglass } \\
\text { fabric-carbon fibre }\end{array}$ & 9.5 & 33.8 & 43,622 & 76,339 & 196,300 & $>8375.5$ & NA \\
\hline 4322 & $\begin{array}{l}4.8 \mathrm{~mm} \text { cell; } \\
96.1 \mathrm{~kg} / \mathrm{m}^{3} \\
\text { aramid } \\
\text { honeycomb }\end{array}$ & $\begin{array}{c}\text { Modified } \\
\text { epoxy }\end{array}$ & $\begin{array}{l}\text { Top face: } 0.61 \mathrm{~mm} \\
\text { fibreglass }- \text { phenolic } \\
\text { Bottom face: } 0.56 \mathrm{~mm} \\
\text { fibreglass-phenolic }\end{array}$ & 9.5 & 33.4 & NA & $>61682$ & 165,764 & $>8724.4$ & 93.1 \\
\hline 4323 & $\begin{array}{l}4.8 \mathrm{~mm} \text { cell; } \\
96.1 \mathrm{~kg} / \mathrm{m}^{3} \\
\text { aramid } \\
\text { honeycomb }\end{array}$ & $\begin{array}{c}\text { Modified } \\
\text { epoxy }\end{array}$ & $\begin{array}{l}\text { Top face: } 0.76 \mathrm{~mm} \\
\text { fibreglass-phenolic } \\
\text { Bottom face: } 0.51 \mathrm{~mm} \\
\text { fibreglass }- \text { phenolic }\end{array}$ & 12.6 & 36.2 & NA & $>106176$ & 242,845 & $>8724.4$ & 239.3 \\
\hline
\end{tabular}


Table 5.8 Physical and mechanical properties of sandwich panels used by Boeing and Douglas aircraft

\begin{tabular}{|c|c|c|c|c|c|c|c|c|}
\hline \multirow[b]{4}{*}{ Product } & \multirow[b]{2}{*}{$\begin{array}{l}\text { Stabilized } \\
\text { compressive } \\
\text { strength } \\
\text { (MPa) }\end{array}$} & \multirow[b]{2}{*}{$\begin{array}{l}\text { In-plane } \\
\text { shear } \\
\text { strength } \\
\text { (MPa) }\end{array}$} & \multirow[b]{2}{*}{$\begin{array}{l}2 \text { lb } \\
\text { Gardner } \\
\text { impact } \\
(\mathbf{N ~ m m})\end{array}$} & \multirow[b]{2}{*}{$\begin{array}{l}\text { Insert } \\
\text { shear } \\
\text { strength } \\
\text { (N) }\end{array}$} & \multirow[b]{2}{*}{$\begin{array}{l}\text { Roller cart } \\
\text { (number of } \\
\text { cycles to } \\
\text { failure) }\end{array}$} & \multicolumn{2}{|c|}{$\begin{array}{c}\text { 30-day } 97 \% \text { humidity } \\
\text { soak }\end{array}$} & \multirow[b]{4}{*}{ Specifications } \\
\hline & & & & & & $\begin{array}{l}508 \mathrm{~mm} \\
\text { flexure } \\
\text { strength } \\
(\mathrm{N})\end{array}$ & $\begin{array}{l}\text { Climbing } \\
\text { drum peel } \\
(\mathbf{N} \text { mm) }\end{array}$ & \\
\hline & \multicolumn{7}{|c|}{ Testing methods } & \\
\hline & $\begin{array}{l}\text { Military } \\
\text { standard } \\
\text { 401B }\end{array}$ & $\begin{array}{l}\text { BMS 4- } \\
\text { 17D }\end{array}$ & $\begin{array}{l}\text { Model } \\
11 \mathrm{~K} 3\end{array}$ & $\begin{array}{l}\text { Shur-Lok } \\
\text { 5107-A3 }\end{array}$ & $\begin{array}{l}\text { Military } \\
\text { standard and } \\
\text { DAC Dwg } \\
7954400\end{array}$ & \multicolumn{2}{|c|}{ Military standard 401B } & \\
\hline 4409 Ty II & 13.40 & 2.47 & $21,827.7$ & 62,423 & $120076 / 36781$ & $13,173.9$ & $19,994.1$ & Boeing BMS 4-20 \\
\hline 4409 Ty III & 5.61 & 2.34 & $22,160.0$ & 57,669 & 82,300 & $12,170.6$ & $21,052.0$ & Boeing BMS 4-20 \\
\hline 4417 Ty I & 5.83 & 2.65 & $145,148.3$ & 80,221 & 83,964 & $10,643.8$ & $43,212.0$ & Boeing BMS 4-17 \\
\hline 4417 Ty II & 14.00 & 3.06 & $119,664.2$ & 85,368 & $121020 / 38427$ & $10,992.8$ & $57,616.1$ & Boeing BMS 4-17 \\
\hline 4417 Ty III & 15.42 & 2.63 & $183,928.5$ & 84,234 & $120001 / 35083$ & $12,999.4$ & 54292.2 & Boeing BMS 4-17 \\
\hline 4417 Ty IV & 5.32 & 2.81 & $140,716.3$ & 71,986 & 83,804 & $20,066.2$ & $55,400.2$ & Boeing BMS 4-17 \\
\hline
\end{tabular}




\begin{tabular}{|c|c|c|c|c|c|c|c|c|}
\hline 4509 Ту 1 & 10.88 & 2.84 & $28,808.2$ & $57974^{\mathrm{a}}$ & 111,002 & $21,025.9$ & $28,586.4$ & $\begin{array}{l}\text { Douglas DAC } \\
\text { Dwg } 7954400 \text {, } \\
\text { ty } 1\end{array}$ \\
\hline 4509 Ту 2 & 3.96 & 2.79 & $26,592.0$ & $49380^{\mathrm{a}}$ & NR & $17,885.1$ & $24,597.6$ & $\begin{array}{l}\text { Douglas DAC } \\
\text { Dwg } 7954400 \text {, } \\
\text { ty } 1\end{array}$ \\
\hline 5424 Ty I & 7.49 & 3.14 & $122,988.3$ & 85,150 & $\begin{array}{c}83570 \text { (no } \\
\text { failure) }\end{array}$ & $10,731.1$ & $55,400.2$ & Boeing BMS 4-23 \\
\hline 5424 Ty II & 12.25 & 3.11 & $190,576.5$ & 88,248 & $\begin{array}{c}121652 \text { (no } \\
\text { failure) }\end{array}$ & $11,647.1$ & $592,824.6$ & Boeing BMS 4-23 \\
\hline $5433 \mathrm{C}$ & NR & NR & 34,348 & NR & NR & NR & NR & $\begin{array}{l}\text { Boeing BMS } \\
7-326 \text { ty VII, } \\
\text { CI } 2 / 1\end{array}$ \\
\hline
\end{tabular}

$F R P$, fibreglass-reinforced plastic; $N R$, not required by customer specification.

${ }^{\mathrm{a}}$ Called insert membrane.

Adapted from Doorway, M.C.G., 1997. Simplified Sandwich Panel Design. 34 (3), M.C. Gill Corp. 
Table 5.9 Physical and mechanical properties of sandwich panels used by Airbus Industry aircraft

\begin{tabular}{|c|c|c|c|c|c|c|c|c|c|c|}
\hline \multirow{4}{*}{$\frac{\text { Product }}{4105}$} & $\begin{array}{l}\text { Compressive } \\
\text { fatigue } \\
2 \times 10^{6} \\
\text { cycles }\end{array}$ & $\begin{array}{l}\text { In-plane } \\
\text { panel } \\
\text { shear }(\mathbf{N})\end{array}$ & $\begin{array}{l}\text { Building } \\
\text { fatigue } \\
\text { lower } \\
\text { limit } \\
1483.2 \mathrm{~N} \\
\text { and } \\
\text { upper } \\
\text { limit } \\
14700.7 \mathrm{~N} \\
2 \times 10^{6} \\
\text { cycles }\end{array}$ & $\begin{array}{l}\text { Roller cart } \\
\text { strength (test } \\
\text { cycles to failure) }\end{array}$ & $\begin{array}{l}\text { Insert } \\
\text { pull-out } \\
(\mathrm{N})\end{array}$ & Flammability & $\begin{array}{l}\text { Smoke D, } \\
\text { flaming } \\
240 \mathrm{~s} \\
\text { nonflaming } \\
240 \mathrm{~s}\end{array}$ & $\begin{array}{l}\text { Toxic } \\
\text { gas } \\
\text { emission }\end{array}$ & $\begin{array}{l}\text { Heat } \\
\text { release }\end{array}$ & $\begin{array}{l}\text { Oil } \\
\text { burner }\end{array}$ \\
\hline & \multicolumn{10}{|c|}{ Testing methods } \\
\hline & \multicolumn{5}{|c|}{$\begin{array}{c}\text { Airbus Industrie TL 53/5000/79 (Gillfab 4105) and DAA/MBB/A1 } 5360 \\
\text { M1B } 000100(\text { Gillfab 4205, } 4322 \text { and 4323) }\end{array}$} & \multicolumn{3}{|c|}{ DAA/ATS 1000.001} & \multicolumn{2}{|c|}{$\begin{array}{c}\text { Far 25.853/FAR } \\
26.855\end{array}$} \\
\hline & NA & 29,000 & NA & $\begin{array}{l}5583.6 \mathrm{~N}-120000 \\
6892.3 \mathrm{~N}-35000\end{array}$ & $74,157.7$ & PASS & NA & NA & NA & NA \\
\hline 4205 & PASS & 24,100 & PASS & $\begin{array}{l}5583.6 \mathrm{~N}-120000 \\
6892.3 \mathrm{~N}-35000\end{array}$ & $100,331.0$ & PASS & $\begin{array}{l}34 \\
2\end{array}$ & PASS & $44.4 / 44.3$ & NA \\
\hline 4322 & NA & NA & NA & NA & $74,157.7$ & PASS & $\begin{array}{l}60 \\
3\end{array}$ & PASS & $45 / 45$ & PASS \\
\hline 4323 & NA & NA & NA & NA & $73,241.6$ & PASS & $\begin{array}{l}83 \\
7\end{array}$ & PASS & $43.6 / 37$ & PASS \\
\hline
\end{tabular}

$F R P$, fibreglass-reinforced plastic; $N A$, not applicable.

Adapted from Doorway, M.C.G., 1997. Simplified Sandwich Panel Design. 34 (3), M.C. Gill Corp. 
Table 5.10 Typical sandwich composite applications by industry

\begin{tabular}{|c|c|c|c|c|}
\hline \multicolumn{5}{|c|}{ Industry } \\
\hline Aircraft & Aerospace & Electronics & Transportation & Construction \\
\hline $\begin{array}{l}\text { Floor panels } \\
\text { Interior walls } \\
\text { Food-handling galley } \\
\text { assemblies } \\
\text { Wing control surfaces } \\
\text { Passenger storage racks } \\
\text { Thrust deflector } \\
\text { assemblies }\end{array}$ & $\begin{array}{l}\text { Capsule panels } \\
\text { Ablative shields for } \\
\text { nose cones } \\
\text { Instrumentation } \\
\text { enclosures and } \\
\text { shelves } \\
\text { Bulkhead panels } \\
\text { Space satellites }\end{array}$ & $\begin{array}{l}\text { Electronic radome } \\
\text { construction } \\
\text { Large antenna or disk } \\
\text { reflectors } \\
\text { Military electronic } \\
\text { instrumentation } \\
\text { shelters } \\
\text { Shipboard electronic } \\
\text { deck shelters }\end{array}$ & $\begin{array}{l}\text { Cargo pallets } \\
\text { Shipping containers } \\
\text { Refrigeration panels } \\
\text { Rapid transit floor } \\
\text { panels } \\
\text { Special automobile } \\
\text { bodies }\end{array}$ & $\begin{array}{l}\text { Architectural curtain } \\
\text { walls } \\
\text { Floor panels } \\
\text { Partitions and divider } \\
\text { panels } \\
\text { Expandable hospital } \\
\text { shelters }\end{array}$ \\
\hline
\end{tabular}




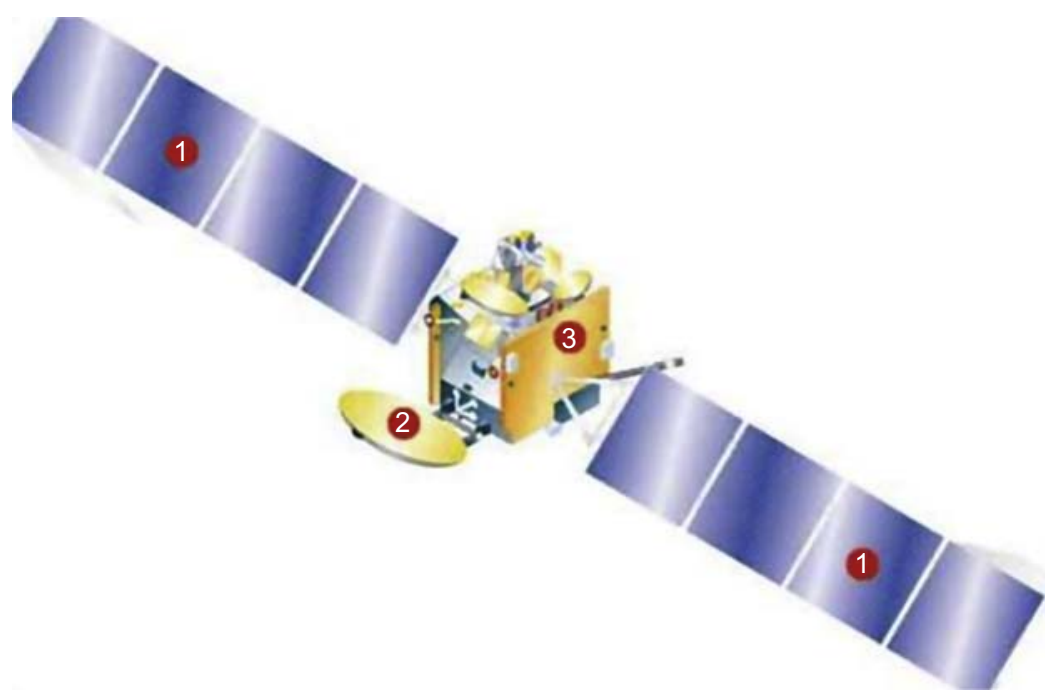

Figure 5.11 Sandwich composites applied in satellites.

(a)

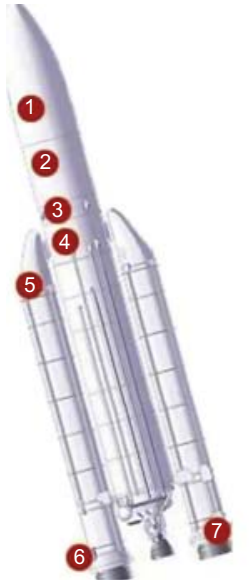

(b)

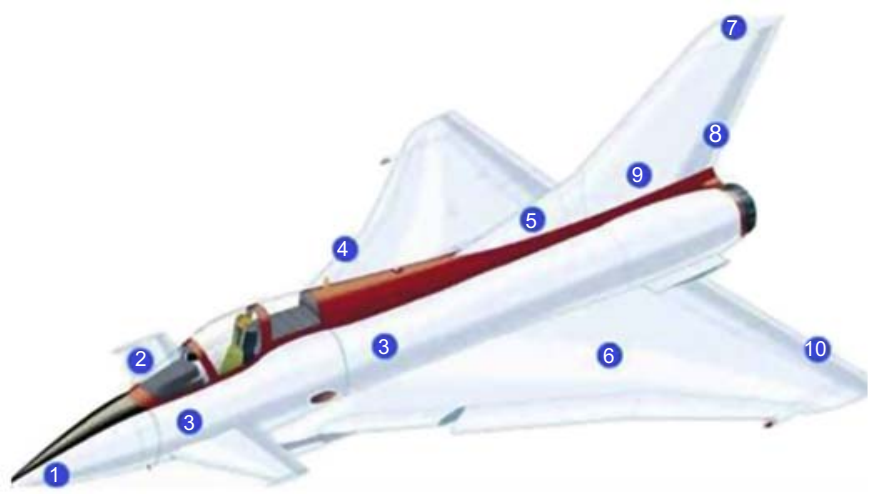

Figure 5.12 Aerospace and aeronautical applications: (a) aerospace; (b) aeronautical.

(6) carbon-epoxy filament winding in the yoke; and (7) carbon prepreg and hightemperature-resistant glass fabric in the heat shield.

Fig. 5.12(b) shows the following for the aeronautical industry: (1) epoxy or BMI prepregs and woven preforms (socks) applied in the radar transparent radomes; (2) carbon-epoxy prepregs in the foreplane canard wings; (3) carbon-epoxy prepregs, nonmetallic honeycomb cores and adhesives in the fuselage panel sections; (4) carbon 


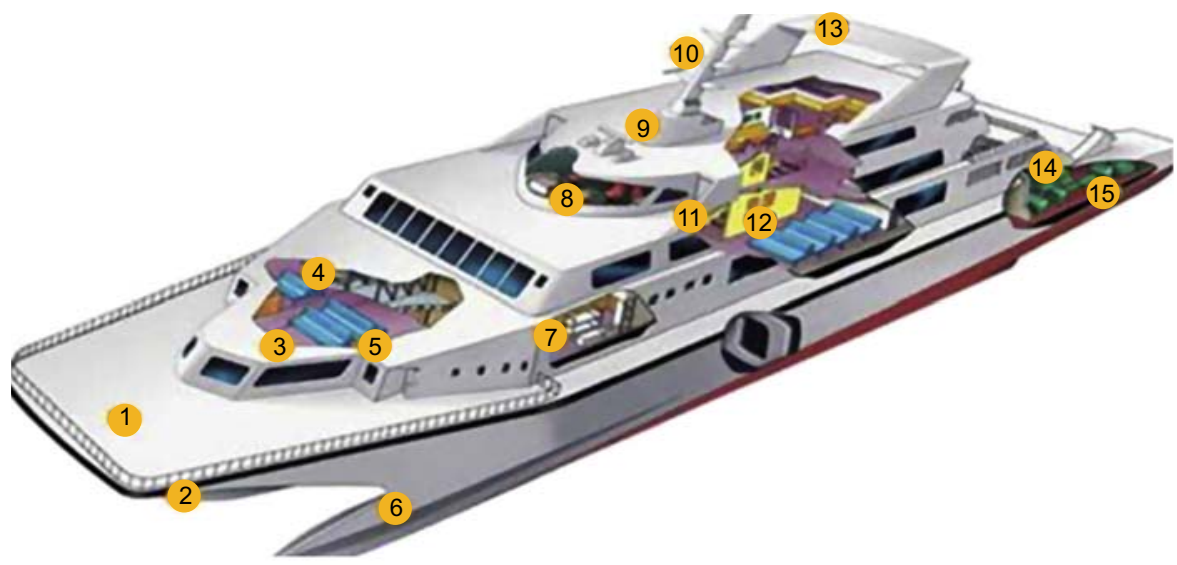

Figure 5.13 Application of sandwich composites in naval construction.

and glass-epoxy prepregs applied in the leading-edge devices; (5) fin fairings; (6) wings and ribs; (7) epoxy-quartz prepregs in fin tip; (8) rudder; (9) fin; and (10) carbon and glass-epoxy prepregs, honeycomb core and adhesives applied in the flying control surfaces.

Finally, some applications where sandwich composites are typically applied in naval construction are shown in Fig. 5.13, such as: (1) decking; $(2,6)$ hull skin structures; (3) lightweight floor structures; (4) suspended ceilings; (5) interior furnishings;

(7) accommodation cabin units; (8) bridge deck consoles; (9) weather shields; (10) communications equipment; (11) companionway stairs; (12) partitions; (13) lightweight superstructures; (14) products for fire, smoke, and toxicity (FST) and sound attenuation in the engine room; and (15) drive shafts and couplings.

\subsection{Design of sandwich structures}

The suitable design of sandwich structures is one of the most important steps to enhance and ensure their best performance in service. The major analytical equations and methods that should be used to design composite sandwich structures and ensure they withstand the most relevant predictable service loadings will be addressed, presented and discussed in this chapter. As in many other cases, the design of composite sandwiches with complex geometry or submitted to combined and/or much more complex loading situations may require the application of computer-aided engineering software programmes (eg, Abaqus ${ }^{\circledR}$ or Ansys ${ }^{\circledR}$ ). These software programmes allow predicting and simulating the mechanical behaviour of the structures in conditions of service by using advanced numerical methods, such as finite element analysis (FEA) or finite difference method (FDM).

This section introduces briefly some of the more relevant and simple loading situations to be considered in the mechanical design. 


\subsubsection{Modes of failure under flexure}

Sandwich composites are primarily used as structural beams submitted to bending and must ensure they get necessary stiffness to avoid excessive deformations in load conditions. Thus, first of all, designers must verify that maximum admissible deformations (deflections) are never reached in the sandwich structure in the worst loading service conditions (Fig. 5.14). Typically, such a situation depends only on the load conditions and the sandwich panel bending and shear stiffness (HexWeb; Doorway, 1997).

Another basic design confirmation concerns the verification that both composite facing-skin laminates (see the first case in Table 5.11) and sandwich core are able to withstand the tensile, compressive and shear stresses induced in the worst service loading conditions. In the same conditions, the skin-to-core adhesive also must be capable of transferring the developed shear stresses between skin and core.

Table 5.11 summarizes the major mechanical failure modes to be verified by the designer.

In the design sandwich composite structures, two different cases also must be considered: sandwich beams or sandwich plates. In the case of sandwich beams, the width-length ratio must be lower than one-third ( $b / L<1 / 3$; see Fig. 5.15), and, in contrast, if this ratio is greater than one-third $(b / L \geq 1 / 3)$, the structure must be considered a plate and the more complex and involved plate theory must be used in the calculations.

\subsubsection{Sandwich composite beams}

Consider a sandwich composite beam of span $L$ and width $b$, submitted to three-point bending with a central load $W$ per unit width in the conditions defined in Fig. 5.15.

Assuming also the same thickness, $t$, for both composite facing skins and a thickness, $c$, for the core, that the beam bends in a cylindrical manner with no curvature in the $y z$ plane, the cross-sections remain plane and perpendicular to the longitudinal axis

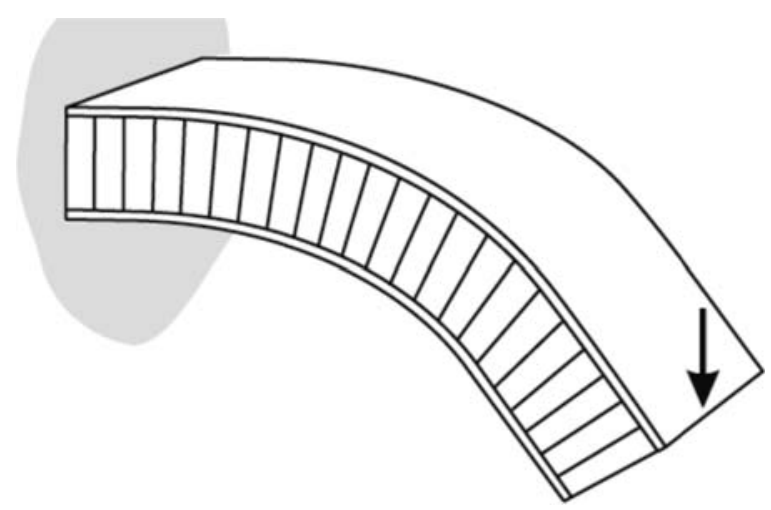

Figure 5.14 Excessive deflection in bending (HexWeb). 


\section{Table 5.11 Major failure modes of sandwich structures}

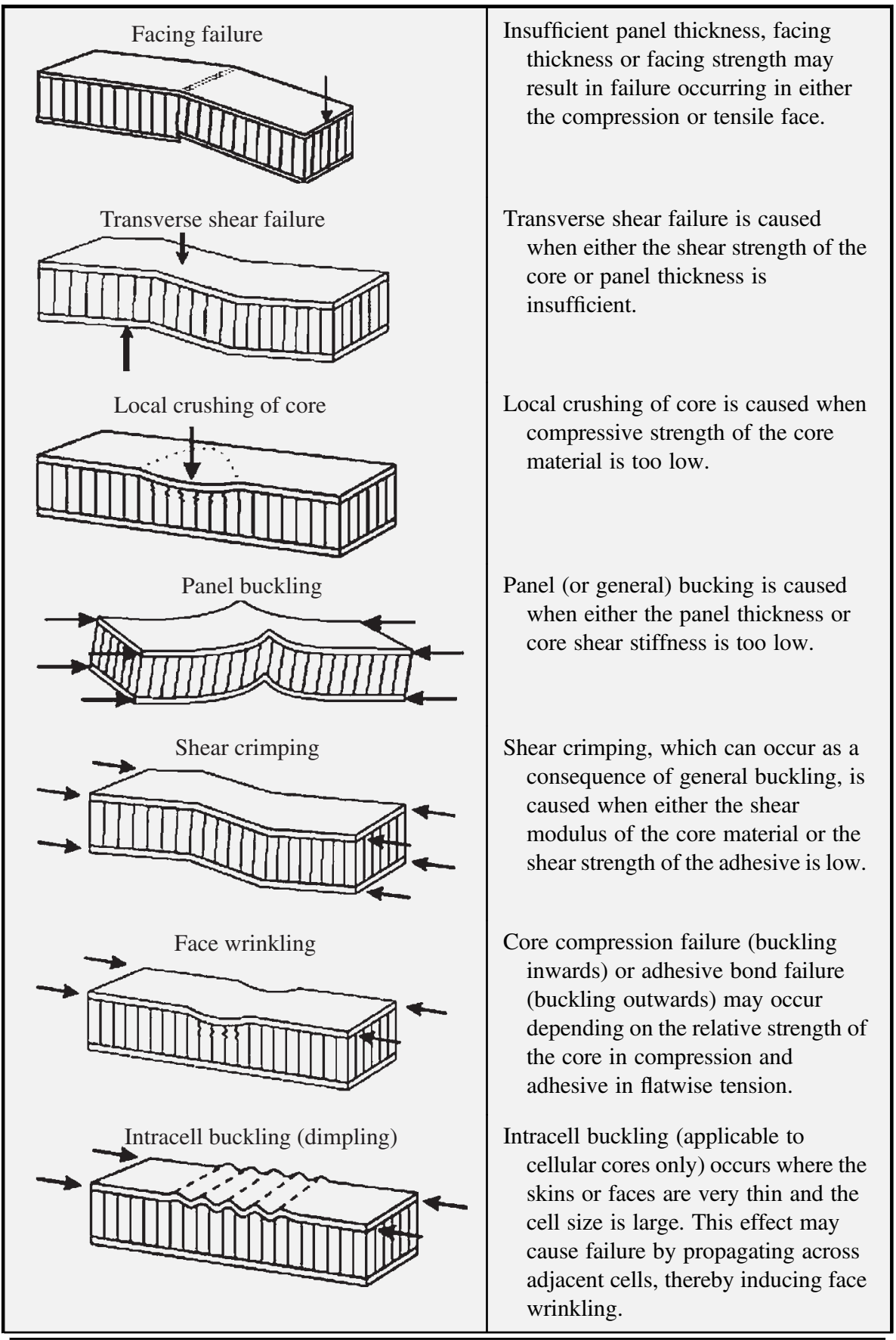

Adapted from HexWeb ${ }^{\text {TM }}$ Honeycomb Sandwich Design Technology. Hexcel ${ }^{\mathbb{R}}$ Technology Manuals. <http://www.hexcel. com/resources/technology-manuals> (visit on 19.03.15.); Broughton, W.R., Crocker, L.E., Gower, M.R.L., January 2002. Design Requirements for Bonded and Bolted Composite Structures. NPL Report MATC(A) 65, NPL Materials Centre National Physical Laboratory, Middlesex, UK. 
(a)

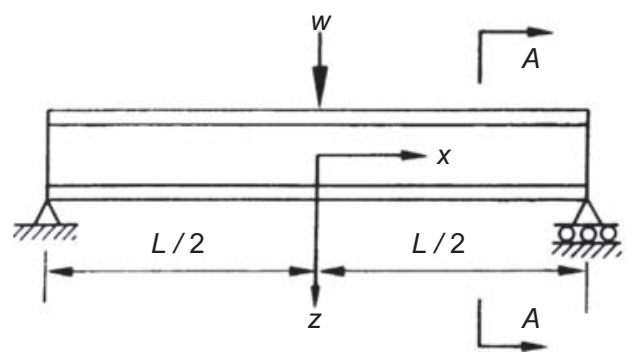

(b)

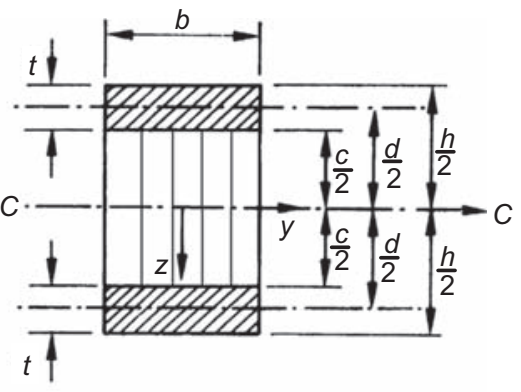

Figure 5.15 Sandwich composite beam submitted to three-point bending: (a) simple supported sandwich beam; (b) sandwich beam cross-section.

and sandwich skins remain firmly bonded to core the flexural stiffness of the sandwich beam, $D$, may be calculated as:

$$
D=\frac{E_{\mathrm{s}} \cdot b \cdot t^{3}}{6}+\frac{E_{\mathrm{s}} \cdot b \cdot t \cdot d^{2}}{2}+\frac{E_{\mathrm{c}} \cdot b \cdot c^{3}}{12}
$$

where (see also Fig. 5.15):

$E_{\mathrm{s}}$ and $E_{\mathrm{c}}$ are the in-plane Young's moduli of the laminate facing skin and core in the $x$ direction, respectively;

$d$ is the distance between the midplanes of the upper and bottom skins; and

$c$ is the core thickness.

In almost of cases as $\frac{d}{t}>5.77$ and $\frac{E_{\mathrm{s}}}{E_{\mathrm{c}}} \cdot \frac{t}{c} \cdot\left(\frac{d}{c}\right)^{2}>16.7$, the first and third terms of Eq. [5.1] may be negligible because they amount to less than $1 \%$ of the flexural stiffness of the beam, which means it could be calculated by using the following simplified equation:

$$
D=\frac{E_{\mathrm{s}} \cdot b \cdot t \cdot d^{2}}{2}
$$

The shear stiffness of the sandwich beam, $S$, is determined by:

$$
S=b \cdot d \cdot G_{\mathrm{c}}
$$

where $G_{\mathrm{c}}$ is the core shear modulus that must be considered equal, as appropriate, to the core shear modulus in the ribbon, $G_{\mathrm{L}}$, or transverse, $G_{\mathrm{W}}$, direction:

$$
G_{\mathrm{c}}=G_{\mathrm{L}} \quad \text { or } \quad G_{\mathrm{c}}=G_{\mathrm{W}}
$$

Table 5.12 shows the most common bending conditions that sandwich composite beams may withstand. 
Table 5.12 Values to be used on beams loaded in different bending conditions (HexWeb)

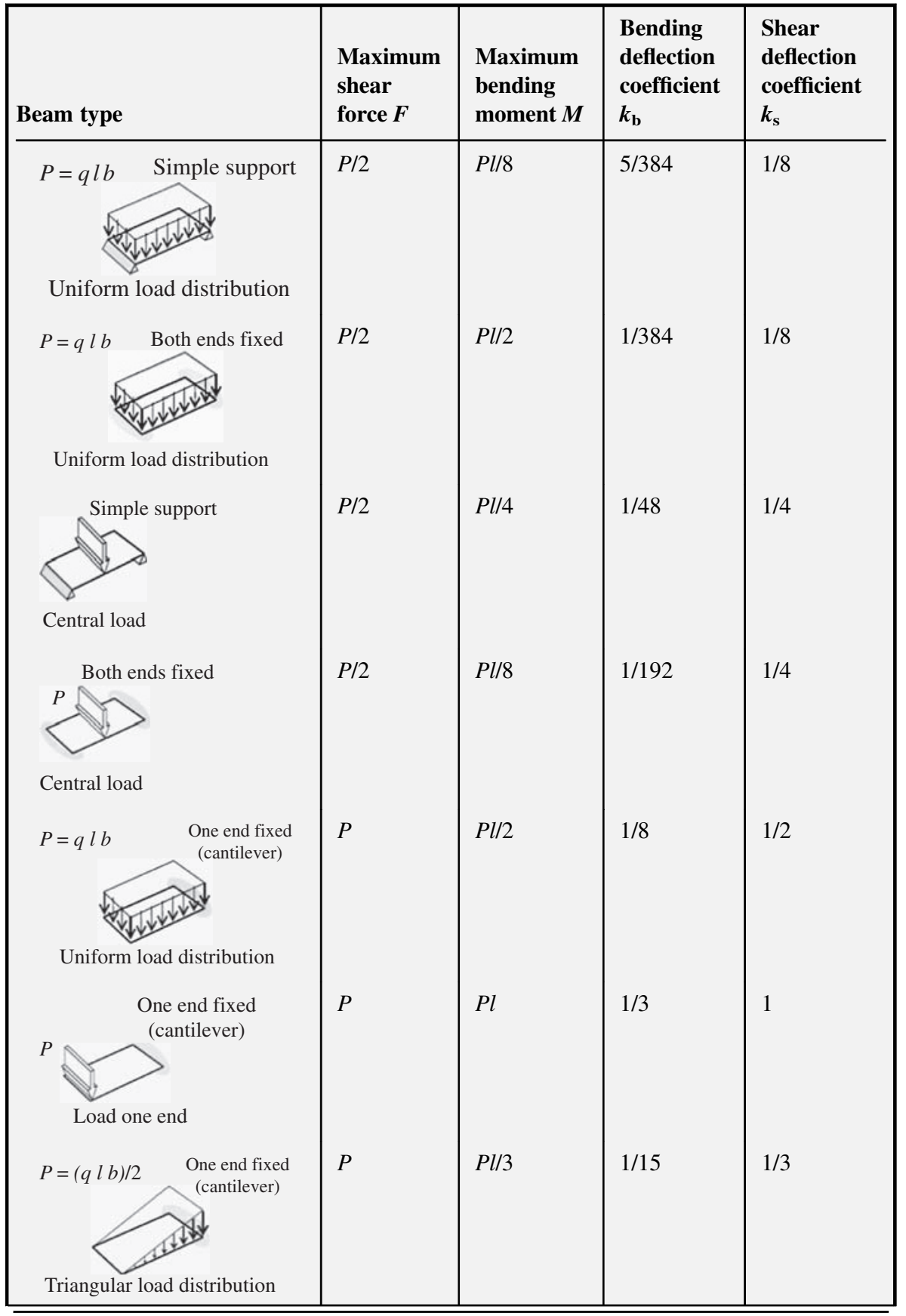

$q$, the uniformly distributed load. 
The maximum deflection in the sandwiched composite beam (Fig. 5.14) may be calculated as:

$$
\delta=\frac{k_{\mathrm{b}} \cdot P \cdot L^{3}}{D}+\frac{k_{\mathrm{s}} \cdot P \cdot L}{S}
$$

where:

$k_{\mathrm{b}}$ and $k_{\mathrm{s}}$ are the deflection coefficients given in Table 5.12 for each bending case;

$L$ is the total sandwich beam length; and

$D$ and $S$ are the sandwich beam bending and shear stiffness, respectively.

The values of the deflection calculated from Eq. [5.5] must be compared with the maximum allowable deflection required in the beam design.

\subsubsection{Sandwich plates}

As was stated in Section 5.3.1, when the ratio between the width, $b$, and length, $a$, is equal to or exceeds one-third (see Fig. 5.16), the beam theory must be replaced by the much more complex and involved plate theory.

The present text only presents solutions for the case, shown in Fig. 5.16, of a sandwich composite plate submitted to a uniformly distributed load and supported on all its four sides. In these conditions, some new coefficients and charts will be introduced and provided in the design calculations, such as:

$$
\lambda=1-\mu^{2}
$$

where:

$\mu$ is the Poisson's ratio of the facing skin material (in the previous calculations of the beam submitted to the end loading condition, it was assumed that $\lambda=1$ ).

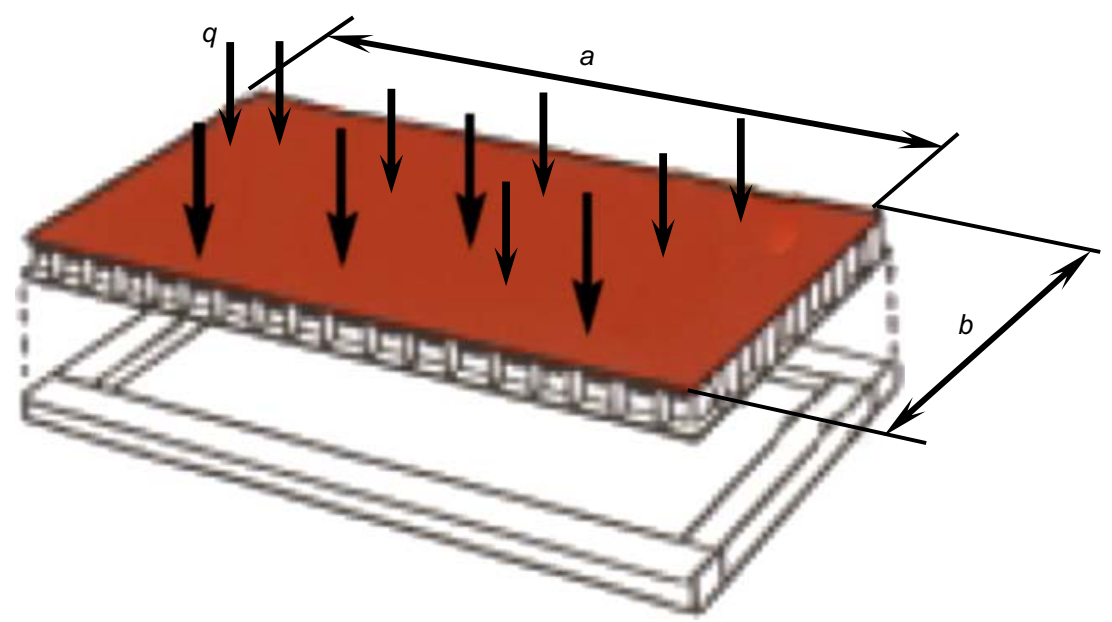

Figure 5.16 Sandwich composite plate simply supported on all four sides. 


$$
R=\frac{G_{\mathrm{L}}}{G_{\mathrm{W}}}
$$

where:

$G_{\mathrm{L}}$ and $G_{\mathrm{W}}$ are the core shear moduli in the ribbon and transverse directions, respectively; and

$$
V=\frac{\pi^{2} \cdot E_{\mathrm{S}} \cdot t \cdot d}{2 \cdot b^{2} \cdot G_{\mathrm{W}} \cdot \lambda}
$$

where (see also Fig. 5.15):

$E_{\mathrm{S}}$ is the laminate facing skin's Young's modulus;

$t$ is the facing skin's thickness;

$d$ is the distance between the midplanes of the upper and bottom skins;

$b$ is the plate width;

$G_{\mathrm{W}}$ is the core shear modulus in the transverse direction; and

$\lambda$ is the parameter calculated by Eq. [5.13].

After determining the value of coefficient $K_{1}$ from the chart depicted in Fig. 5.17, the total deflection, $\delta$, of the plate submitted to the uniformly distributed load, $q$, may be calculated by:

$$
\delta=\frac{2 \cdot K_{1} \cdot q \cdot b^{4} \cdot \lambda}{E_{\mathrm{S}} \cdot t \cdot d^{2}}
$$

\subsubsection{Skin failure}

\subsubsection{Sandwich beams}

The maxima tensile and compressive stresses, $\sigma_{\mathrm{S}}$, in the facing-skin laminates of the beam may be determined by Eq. [5.10]:

$$
\sigma_{\mathrm{S}}= \pm \frac{M}{d \cdot t \cdot b}
$$

where:

$M$ is the maximum bending moment the sandwich beam has to withstand. Table 5.12 presents the maximum bending moment to be considered in the most common flexion cases.

The stress calculated from Eq. [5.10] must be compared with the maximum allowable stress that the laminate facing skin can support.

End loading conditions (see Fig. 5.18) may also cause skin failure due to excessive stress, sandwich panel buckling failure (the fourth line of Table 5.11), intracell dimpling or face wrinkling (the last two cases given in Table 5.11). 

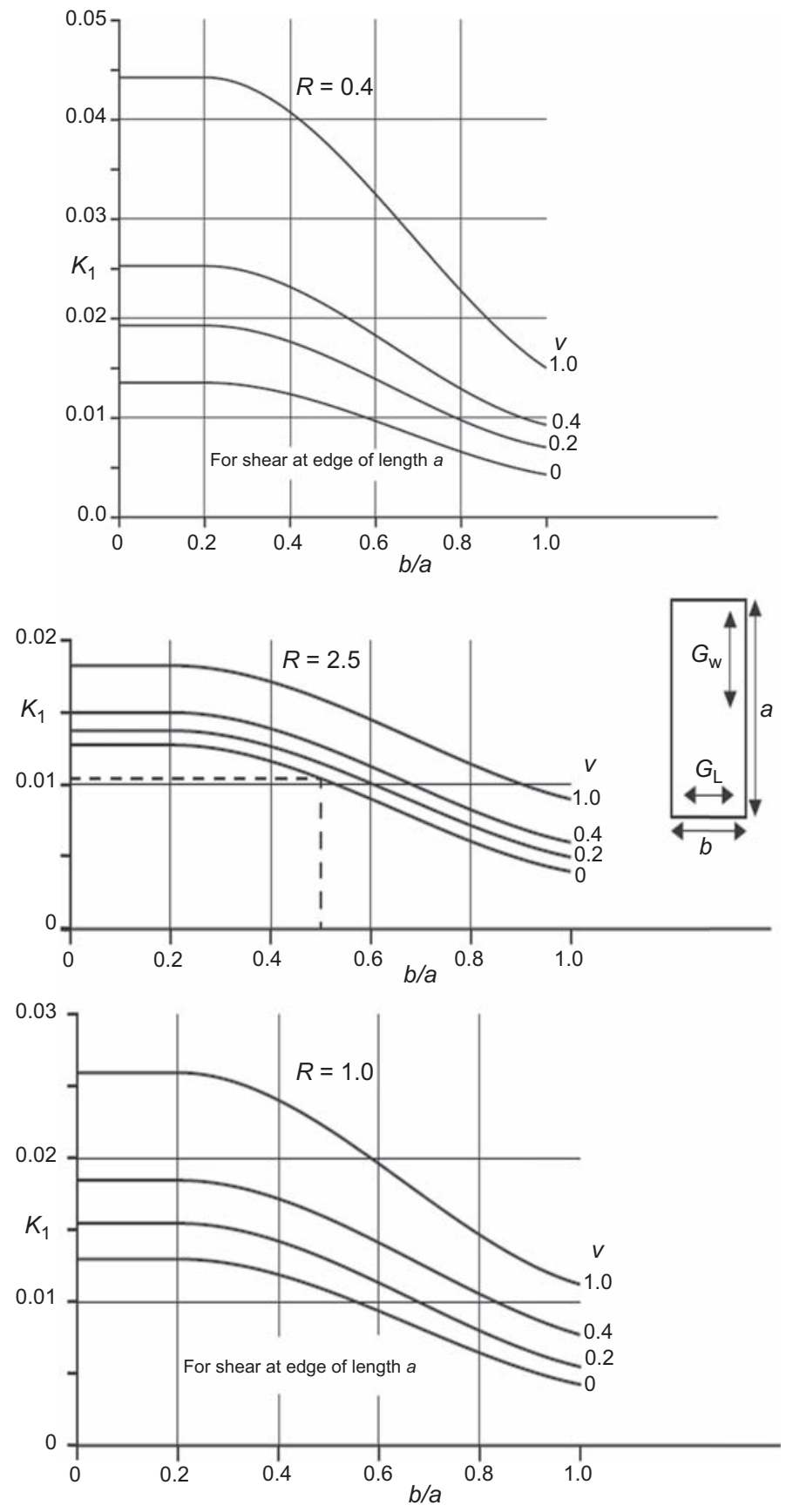

Figure 5.17 Charts for determining the coefficient $K_{1}$. 


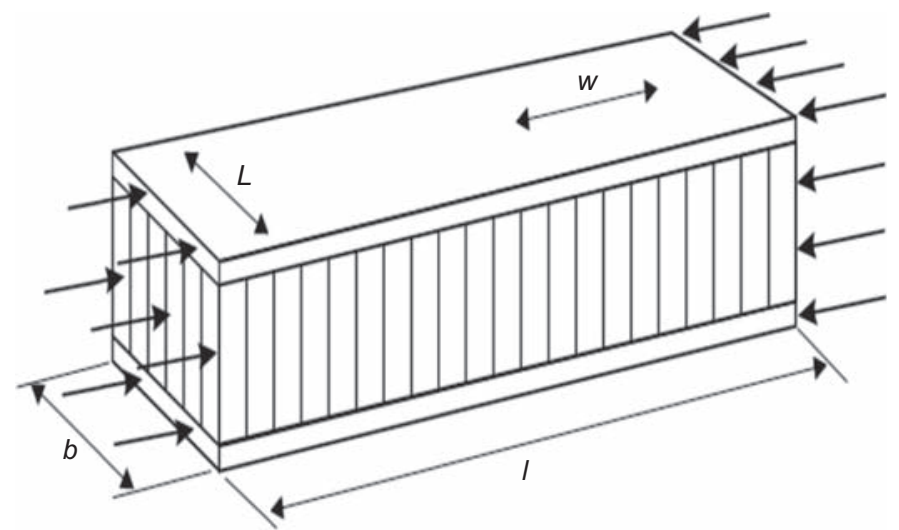

Figure 5.18 Sandwich composite beam submitted to end loading conditions.

By considering that the end applied load, $P$, is supported by both skins with the same thickness, $t$, the stress developed in the facing skins may be calculated as:

$$
\sigma_{\mathrm{S}}=\frac{P}{2 \cdot t \cdot b}
$$

where $b$ is the panel width.

If the end load is applied with uniform distribution along length, $q$, the total load to be considered in Eq. [5.11], $P$, is calculated as:

$$
P=q \times b
$$

As happens in bending, the stress calculated by Eq. [5.11] must be lower than the maximum allowable one that the laminate facing skins support to ensure they do not suffer failure.

It is also necessary to ensure that the compressive end load, $P$, does not overpass the sandwich composite beam buckling load, $P_{\mathrm{b}}$ (Table 5.11, fourth line), which may be calculated as:

$$
P_{\mathrm{b}}=\frac{\pi^{2} \cdot D}{l^{2}+\frac{\pi^{2} \cdot D}{G_{\mathrm{c}} \cdot d \cdot b}}
$$

and

$$
|P| \leq\left|P_{\mathrm{b}}\right|
$$


where:

$D$ is the panel flexural stiffness calculated from Eqs [5.1] or [5.2];

$G_{\mathrm{c}}$ is the lower value of the core shear modulus see Eq. [5.4]

$l$ is the beam length; and

$d$ is the distance between the midplanes of the upper and bottom skins (see Fig. 5.15).

Furthermore, to avoid buckling of the facing skins where they are unsupported by the honeycomb walls, the following intracell buckling (dimpling) stress, $\sigma_{\mathrm{CR}}^{d}$, must not be exceeded in the skins:

$$
\sigma_{C R}^{d}=2 \times E_{\mathrm{S}} \times\left[\frac{t}{s}\right]^{2}
$$

where (see also Fig. 5.15):

$E_{\mathrm{S}}$ is the laminate facing skin's Young's modulus;

$t$ is the facing skin's thickness; and

$s$ is the size of the core cell.

Finally, wrinkling and buckling may occur in facing skins with a wavelength greater than the core cell width at higher stresses than the critical one, $\sigma_{\mathrm{CR}}^{W}$, which is given by Eq. [5.16]:

$$
\sigma_{\mathrm{CR}}^{W}=0.5 \times\left[G_{\mathrm{c}} \cdot E_{\mathrm{c}} \cdot E_{\mathrm{s}}\right]^{1 / 3}
$$

where (see also Fig. 5.15) $E_{\mathrm{c}}$ and $G_{\mathrm{c}}$ are the core Young's and shear moduli, respectively.

\subsubsection{Sandwich plates}

In the case of sandwich composite plates, after determining the coefficient $K_{2}$ from the chart depicted in Fig. 5.19, the maximum facing-skin stress should be calculated as:

$$
\sigma_{\mathrm{s}}=\frac{K_{2} \cdot q \cdot b^{2}}{d \cdot t}
$$

where $K_{2}$ is a coefficient determined from the chart depicted in Fig. 5.19.

\subsubsection{Core failure}

\subsubsection{Sandwich beams}

In sandwich beams under flexure, the core may fail due to excessive shear stress. Thus, the maximum value of such shear stress developed in the core caused by the transverse 


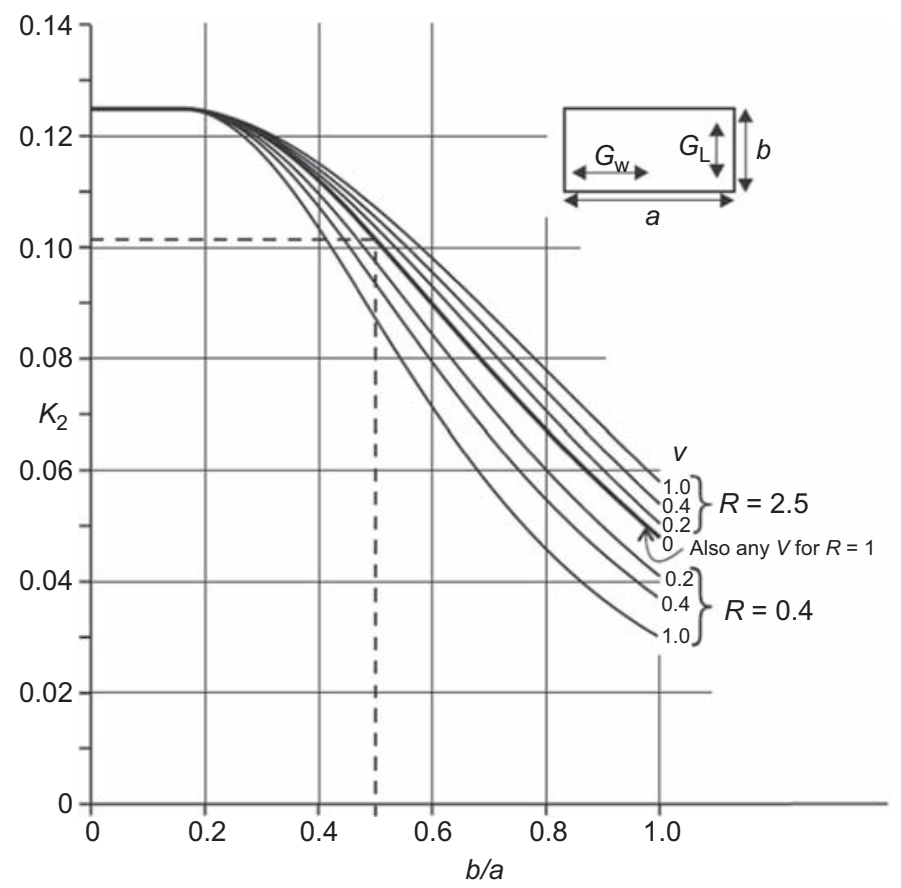

Figure 5.19 Chart for determining the coefficient $K_{2}$ for sandwich plates.

load on the beam (see the second line of Table 5.11), $\tau_{\mathrm{c}}$, calculated from Eq. [5.18], must be lower than the allowable transverse shear stress the core withstands:

$$
\tau_{\mathrm{c}}=\frac{F}{c \cdot b}
$$

where:

$F$ is the maximum shear force shown in Table 5.12 for each bending case; and $c$ and $b$ the core thickness and beam width, respectively.

Furthermore, the core must also resist the local compressive stress cause by the application of the transverse load, $P$ (see the case shown in the third line of Table 5.11). Such compressive stress may be calculated by Eq. [5.19] and must be smaller than the maximum allowable compression stress the core can withstand:

$$
\sigma_{\mathrm{c}}=\frac{P}{A}
$$

where $A$ is the area where the load, $P$, is applied.

Finally, in the case of end loading conditions (see Fig. 5.18), shear crimping failure may also occur in the core as a consequence of buckling that may be caused by a low 
core shear modulus or weak adhesive shear strength. To avoid shear crimping failure, the total end load, $P$, applied to the sandwich beam must be smaller than the shear crimping and buckling, $P_{\mathrm{b}}^{\mathrm{SC}}$, determined as:

$$
P_{\mathrm{b}}^{\mathrm{SC}}=c \times G_{\mathrm{c}} \times b
$$

where:

$c$ is the core total thickness (see Fig. 5.15); and

$G_{\mathrm{c}}$ is the lower value of the core shear modulus (see Eq. [5.4])

\subsubsection{Sandwich plates}

In the case of a sandwich composite plate submitted to a uniformly distributed load and supported on all four sides, previously presented in Fig. 5.16, the maximum shear stress developed in the core, $\tau_{\mathrm{c}}$, may be calculated from:

$$
\tau_{\mathrm{c}}=\frac{K_{3} \cdot q \cdot b}{d}
$$

where:

$K_{3}$ is a coefficient to be determined from the chart depicted in Fig. 5.20;

$q$ is the uniformly applied load;

$b$ is the plate width; and

$d$ is the distance between the midplanes of the upper and bottom beam skins.

The core of the plate must also withstand the same local compressive stress determined for sandwich composite beams by Eq. [5.19], which results from the application of the transverse load, $P$ (see the case shown in the third line of Table 5.11).

\subsubsection{Skin and core interfacial design}

Skin-core bonding must withstand, of course, at least the above-mentioned shear stress developed for the skin and core. Loads that may cause skin-core debonding only can be compared with those associated to other modes of failure (eg, face yielding, face wrinkling and core shearing) if relatively large cracks preexist at the interface. However, debonding may occur as a result of poor manufacturing, localized impact, fatigue or exposure to extremely high temperature.

It is common to consider that skin-core debonding is avoided by ensuring that the preexistent cracks at the skin-core interface do not reach a critical length related to the adhesive critical strain energy release rates in modes I and II ( $G_{\mathrm{Ic}}$ and $\left.G_{\mathrm{IIc}}\right)$, normally determined by using double-cantilever beam (DCB), single-cantilever beam (SCB) and end-notched flexural (ENF) test methods, respectively. Mixed-mode fracture testing methods, which consist of a modified DCB testing setup, may allow determination of the interface fracture behaviour under simultaneous mode I and II conditions. 

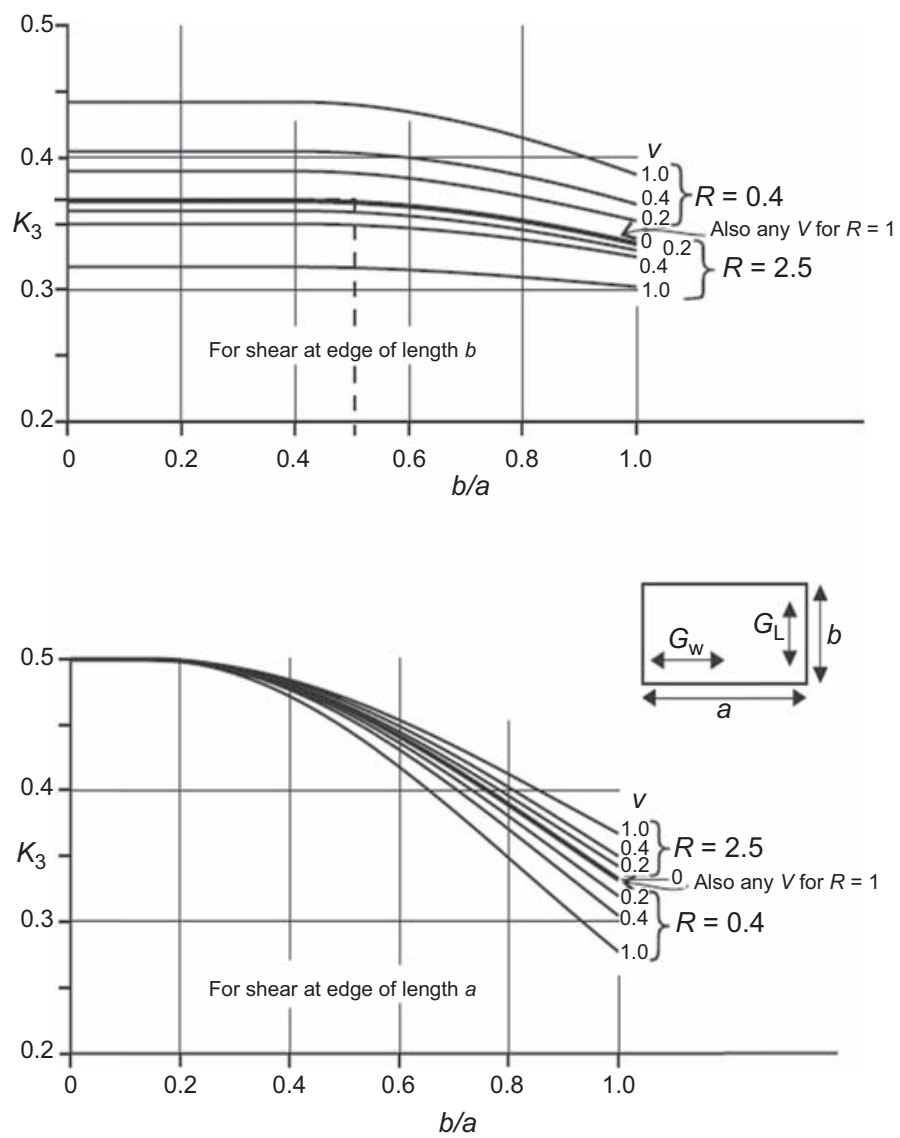

Figure 5.20 Chart for determining the coefficient $K_{3}$.

In the case of the sandwich beam under flexural concentrated load, $w$, depicted in Fig. 5.15, by considering that the critical strain energy release rate in mode II, $G_{\text {IIc }}$, was already determined as the most relevant fracture mode in the considered situation, the maximum allowable critical load that the beam may sustain, $w_{\mathrm{c}}$, may be determined as:

$$
w_{\mathrm{c}}=\sqrt{X \cdot L \cdot b \cdot G_{\mathrm{IIc}}}
$$

where:

$X$ is a ratio between the applied load and deflection see Eq. [5.5], $\frac{w}{\delta}$; and

$G_{\text {IIc }}$ is the critical strain energy release rate in mode II.

Experimental evidence shows that debonding is not likely to occur unless a large crack exists in the interface. Thus, a maximum allowable crack length should be defined for more liable structures in order to be adequately monitored through 
nondestructive quality control tests. In complex real structures and load conditions, studies of skin-core debonding usually require the use of advanced numerical methods, such as FEA or FDM.

\subsection{Quality control, maintenance, testing, inspection and repairing}

This section will discuss the major aspects related to quality control during sandwiched composites manufacturing and their maintenance, testing and repairing in service. Visual, ultrasonic, X-ray, back-light and moisture detectors are some of the techniques reviewed as the main methods commonly used to detect damages in sandwich structures that are applied in aerospace and aircraft parts (Aviation Maintenance Technician Handbook, 2012).

Major manufacturing damage and defects usually include delaminations, resinstarved and resin-rich areas, cracks, blisters and air bubbles, wrinkles, voids and thermal decomposition. This section summarizes the most common nondestructive testing techniques (NDTs) used to detect such defects in quality control inspections made during manufacturing and in-service conditions of composite sandwich structures.

\subsubsection{Nondestructing testing}

Sandwich structures can be subjected to different impact loads that possibly create delamination and debonding damage that needs to be assessed by reliable, efficient, easy-to-use NDT methods. The damage will vary depending on the nature of the composite part, its composition and its density. The most commonly used nondestructive methods to detect damages in sandwich structures applied in aerospace are as follows (Aviation Maintenance Technician Handbook, 2012):

- Visual inspection: This is the primary method for the in-service inspection of sandwich structures. It is fast and has a large field of view, being suitable for detecting impact damages larger than $0.5 \mathrm{~mm}$. It cannot detect delaminations or debondings, and it is not suited for defect sizing and defect depth estimation.

- Audible sonic testing (coin tapping) and automated tap test: This is the most common technique for detecting delamination or debondings. It is performed by tapping with a round disk or a lightweight hammer, and listening to the sound response of the sandwich structure to the hammer. A clear, sharp, ringing sound is indicative of a well-bonded solid structure, whereas a dull or thud-like sound indicates a discrepant area. This inspection must be accomplished by experienced personnel. The automated tap test is similar to the manual tap test, but instead of a hammer a solenoid is used. A transducer and recording system allows saving the force-time signal of the impactor. As the duration of the impact force can be correlated with the stiffness of the structure, a variation of such duration allows one to predict delamination and debonding damages.

- Ultrasonic inspection: This technique uses sound waves with frequencies above the audible range. Ultrasonic waves are introduced into a material where they travel in a straight line and at a constant speed until they encounter an interface (eg, a delamination). At surface interfaces, some of the wave energy is reflected and some is transmitted. The amount of reflected or transmitted energy can be detected and provides information about the damage area. Pulse-echo and through transmission (relates to whether reflected or transmitted energy is 
used), normal beam and angle beam (relates to the angle that the sound energy enters the test sandwich) and contact and immersion (relates to the method of coupling the transducer to the test sandwich) are the most frequently used ultrasonic techniques. Information from ultrasonic testing can be presented in three formats: A-scan (presentation displays the amount of received ultrasonic energy as a function of time) B-scan (presentation displays a cross-section of a test specimen) and C-scan (presentation displays a plain-type view of the test specimen and discontinuities). Using this technique, porosities, inclusions, delaminations and debondings can be detected.

- Radiography: Radiography involves passing X-ray radiation through a composite part and capturing an image on the opposite side through the phenomenon of differential absorption. Areas with varying degrees of density and absorption exhibit different behaviour in terms of absorbed radiation. It can be used to identify voids, water, impact delaminations, crack-damaged cores, insufficient adhesive and entrapment of foreign material during the manufacturing process.

- Thermography: The principle of thermography is to send a heat flow on the surface of an inspected sandwich part during a certain time and then to capture the resulting thermal response. All techniques make use of the different behaviour in terms of thermal conductivity between normal and defected areas. Usually, a heat source is used to elevate the temperature of the composite under examination while observing the heating effects caused by the decrease in thermal conductivity that damaged areas exhibit. Defects such as debondings, delaminations, cracks and the presence of water can be identified.

- Moisture detector: Uses radiofrequency power loss to detect water in sandwich structures.

\subsubsection{Repairing sandwich structures}

Sandwich structures are bonded constructions with thin-face skins that usually can be repaired by bonding. The repair of such kinds of structures uses similar techniques for the most common types of face sheet materials, such as glass or carbon fibre composite shells. The repairs must meet the strength requirements and can be classified as temporary (limited by time; must be removed and replaced), interim (not restoring the required durability to the component and, therefore, having a different inspection interval and/or method) and permanent repairs (restoring both strength and durability). Sandwich structures with minor core damage can be repaired using a potted repair. The core material could be left in place or could be removed and filled up with a potting compound (usually filled epoxy resins) to restore some strength. This technique is also used sometimes for cosmetic repair of skin panels. Structural repair normally consists of using the following steps on the damaged component (Aviation Maintenance Technician Handbook, 2012):

- Inspect the damaged area: Use an NDT method to assess the damaged area.

- Remove the water from the damaged area: This task can be performed using breather cloths and the vacuum bag method.

- Remove the damage: The damaged area must be trimmed out, usually in circular or oval shapes. If the damaged area includes the core, this material must also be removed.

- Prepare the damaged area: The damaged and surrounding areas should be cleaned by using sandpaper, compressed air and approved solvents.

- Installation of the honeycomb core (wet lay-up): The damaged core must be replaced by a plug of the same type and shape, using an adhesive layer or resin to bond it. The vacuum bag technique can be used to cure the core replacement. 


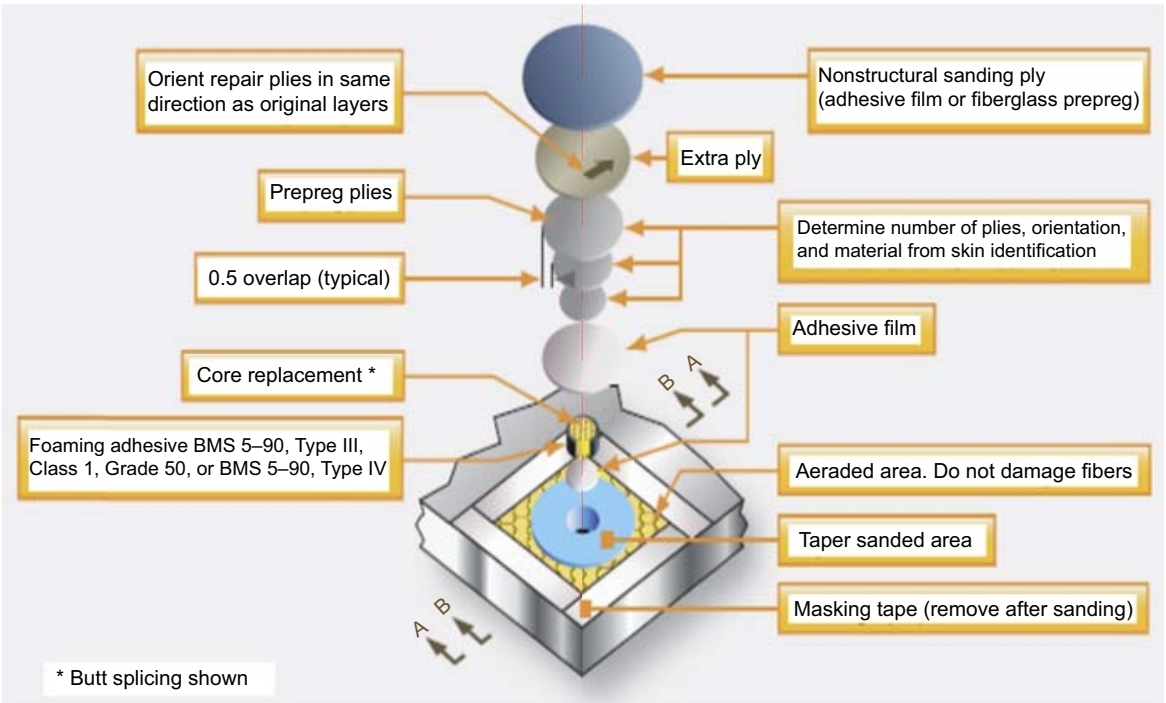

Figure 5.21 Repair ply installation (Aviation Maintenance Technician Handbook, 2012).

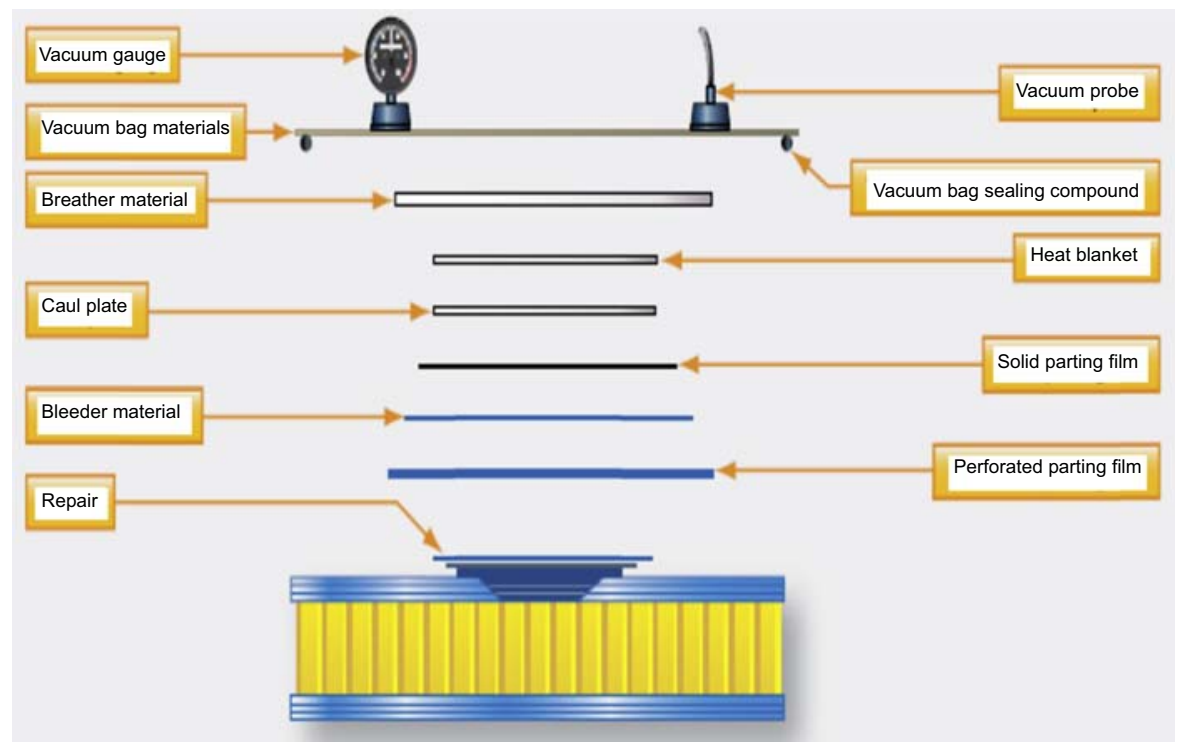

Figure 5.22 Vacuum-processing technology (Aviation Maintenance Technician Handbook, 2012).

- Prepare and install the repair plies: Impregnate or remove the backing material of the repair plies that should have the correct size and ply orientation (Fig. 5.21).

- Vacuum-bag the repair: The vacuum bag technology is usually used to remove air and to pressurize the repair for curing (Fig. 5.22). 
- Cure and inspect the repair: The repair should be cured using the appropriate curing cycle. The repair should be free from pits, blisters and resin-rich and resin-starved areas. Usually, a top finishing coating is applied. Finally, an NDT technique is used to inspect the repaired area and confirm if the repair is free of defects.

\subsection{Conclusions}

Sandwiched composites are of particular interest and widely used because they are very suitable and amenable to the development of lightweight structures with high in-plane and flexural stiffness. In recent years, their application has increased greatly in the automotive and marine industries, and even in primary structures of commercial aircrafts (fuselage). Thus, large growth in the structural applications of those materials in the aerospace industry is forecasted for the coming years.

The main raw materials, manufacturing technologies and design methods to be considered for applying sandwich composites in aerospace structures were briefly presented and discussed in this chapter.

The chapter may be considered as an introduction that does not disregard further fundamental readings on this matter and more specific knowledge on each particular application case.

\section{References}

Advanced Composite Manufacturing Centre. <http://www.tech.plym.ac.uk http://www.tech. plym.ac.uk/sme/acmc/cpd/rtm.htm> (visited 03.06.15.).

Aluminium Honeycombs, Alcore Inc. - A Gill Company, http://www.thegillcorp.com (visit on 28.04.28.).

Aviation Maintenance Technician Handbook-Airframe. Chapter 7: Advanced Composite Materials, vol. 1, 2012. Federal Aviation Administration US Department of Transportation Flight Standards Service.

Balsa Wood Core, Airex AG Industrie, http://www.3accorematerials.com (visit on 28.04.15.).

Beckwith, S.W., July/August 2008. Sandwich core materials \& technologies - Part I. SAMPE Journal 44 (4).

Bitzer, T., 1997. Honeycomb Technology - Materials, Design, Manufacturing Applications and Testing. Chapman \& Hall.

Broughton, W.R., Crocker, L.E., Gower, M.R.L., January 2002. Design Requirements for Bonded and Bolted Composite Structures. NPL Report MATC(A) 65. NPL Materials Centre - National Physical Laboratory, Middlesex, UK.

Doorway, M.C.G., 1997. Simplified Sandwich Panel Design, vol. 34 (3). M.C. Gill Corp.

Hexply-prepreg Technology, Hexcel.

HexWeb ${ }^{\text {TM }}$ Honeycomb Sandwich Design Technology. Hexcel ${ }^{\circledR}$ Technology Manuals. <http:// www.hexcel.com/resources/technology-manuals $>$ (visit on 19.03.15.).

$<$ http://www.nuplex.com/composites/processes/filament-winding $>$ (visited on 03.06.15.).

Marasco, A.I., 2005. Analysis and Evaluation of Mechanical Performance of Reinforced Sandwich Structures: X-cor ${ }^{\mathrm{TM}}$ and K-cor ${ }^{\mathrm{TM}}$. PhD thesis. Cranfield University.

Mazumdar, S.K., 2001. Composites Manufacturing: Materials, Product and Process Engineering. CRC Press. 
Muzzy, J.D., 2000. Thermoplastics - properties. In: Kelly, A., Zweben, C. (Eds.), Comprehensive Composite Materials, vol. 2. Elsevier Ltd, pp. 57-76 (Chapter 2).01.

Noor, A.K. (Ed.), 2000. Structures Technology for Future Aerospace Systems. Progress in Astronautics and Aeronautics, vol. 188. American Institute of Aeronautics and Astronautics. Peters, S.T. (Ed.), 1998. Handbook of Composites, second ed. Chapman \& Hall.

Sezgin, F.E., 2011. Mechanical Behavior and Modeling of Honeycomb Cored Laminated Fiber/ Polymer Sandwich Structures. Master Thesis. İzmir Institute of Technology, Turkey.

van Paepegem, W. Home Made Composites. <http://www.composites.ugent.be/home_made_ composites/organizing_your_composite_workshop.html > (visited on 27.05.15.).

Zenkert, D., 1995. An Introduction to Sandwich Construction. EMAS Publishing. 